\title{
KARINIO VADOVAVIMO SAMPRATA LIETUVOS KARIUOMENĖJE 1930-1940 M.
}

\author{
Kmdr. Itn. Remigijus Zabiela \\ Klaipedos universiteto Baltijos regiono istorijos ir archeologijos institutas, \\ Lietuvos kariuomenès Karinès jüru pajegos
}

\begin{abstract}
Anotacija. Vadovavimo ir vado temos 1930-1940 m. Lietuvos kariuomenes doktrininiuose leidiniuose, periodikoje, įvairiuose dokumentuose ir kitur buvo aptariamos gana dažnai. Visa nagrinejjama laikotarpi šios temos taip ir neišsikristalizavo ì vienq apčiuopiama vadovavimo samprata, kuria kariuomene galètu apibrëžti kaip kertinę doktrina ir kuria remiantis bütų klojami visų lygiu vadovavimo pagrindai ir vykdomas su vadovavimu susijęs karinis rengimas. Todel tarpukariu tarp vadu ir kitu kariu nuolat vyko diskusija, kaip reikètu traktuoti vada ir karini vadovavima.

Siekiant išsiaiškinti, kokia Lietuvos kariuomenèje buvo vadovavimo saprata, šiame straipsnyje analizuojamos trys šaltiniu ir literatūros grupès, o ju esminiai panašumai pabaigoje susiejami i viena apibendrinamają sampratą. Pirmoji grupé - tai doktrininiai Lietuvos kariuomenes dokumentai, apibrěžiantys kariniu vienetu kasdiene ir kovine veikla ir traktuotini kaip oficialioji (formalioji) Lietuvos kariuomenes pozicija vadovavimo klausimais daliniuose, kuria idiegti buvo daliniu vadovybès pareiga, ir kartu mokomoji medžiaga vykdant kasdienị kariu rengima. Antroji grupe yra karinio rengimo ir mokymo įstaigu indèlis i tarpukario karininkijos ir vadovaujančiu puskarininkiu rengima per įvairiu kursu mokymo programas, karo pedagogikos, psichologijos ir karinio rengimo leidinius. Trečiaja grupę sudaro karinès periodikos leidiniai, tokie kaip „Karys“, „Kardas“, „Mūsų žinynas", ir juose išsakyta ịvairiu kariuomenès atstovu pozicija vadovavimo klausimais. Tyrimo chronologinès ribos - XX a. 4-asis dešimtmetis, nes šiuo laikotarpiu pastebimas ženklus su vadovavimo problematika susijusiu klausimu analizei tinkamos medžiagos pagausèjimas.
\end{abstract}

Pagrindiniai žodžiai: vadovavimas, vadas, doktrina, karinis rengimas, karine periodika, tarpukario Lietuvos kariuomene. 


\section{IVADAS}

Karinis vadovavimas yra kur kas sudetingesnis procesas nei apskritai vadovavimas bet kuriai civilinei organizacijai, nes šiuos pasaulius skiria esminis dalykas - karas ir rengimasis jam. Karinio vadovavimo rezultatus sunku išmatuoti prieš mūš̨̌, nes net ir geriausiai treniruotèse pasirodęs kovinis vienetas karo metu gali tapti silpniausia grandimi, dẻl kurios žlunga didesni dalykai. Taigi, skirtingai nuo civilinio vadovavimo, karinis vadovavimas labiau orientuotas $\mathfrak{i}$ nuolat vykstantị procesą, o ne $\mathfrak{i}$ tam tikrą kuriamą produktą, tad jo efektyvumas kasdienèje tarnyboje gali būti vienoks, o kare - visiškai kitoks.

Karinis vadovavimas koviniam vienetui suvokiamas kaip gebejimas paveikti pavaldinius taip, kad jie įvykdytų skirtą užduotị. Vis dèlto kartais net ir geriausi vadai nesugeba priversti karių kautis, kai jie susitinka priešą, nes nebeveikia individualūs valios kautis veiksniai. Kitais atvejais net vado (gero ar prasto) mirtis nesustabdo karių, ir jie toliau tęsia mūšį. Dèl to galima teigti, kad vado svarba dažnai būna pervertinama, bet jei vadai yra kompetentingi ir koviniai vienetai jaučiasi esą gerai parengti, vado poveikis valiai kautis, tikètina, bus pozityvus. Vado kompetencijos neįmanoma patikrinti vien teoriniais būdais, nes ji visiškai atsiskleidžia tik karo veiksmų situacijoje, kai ị veiksmingą visumą reikia sutelkti visus savo gebejjimus ir žinias.

Visa tai ịvertinus ir siekiant karinị vadovavimą vienodai traktuoti toliau analizuojant šią temą, pirmiausia reikètų apibrèžti jo turinị, tikslus ir formas:

1. karinio vadovavimo sąvoka apima terminus „vadovavimas“, „lyderiavimas“ arba „lyderystë“, „valdymas“ ir „vadyba“ (t. y. dalykus, kurie taip vadinami šiu dienų lietuviškose karinèse doktrinose) ir kartu daug ịvairių procesų, pradedant formaliąja valdžios pozicija, ịsakymais, vadybiniu darbu ir baigiant neformaliais santykiais su aukštesniąja valdžia ir pavaldiniais bei administracinių procesų valdymu;

2. karinio vadovavimo funkcijas vykdantis karys idealiu atveju turètu gebèti atlikti ne tik formaliojo (paskirtojo) vado funkcijas, t. y. vadovauti tam tikro lygio hierarchiškai organizacijai, bet ir būti lyderiu, vadybininku, administratoriumi, pedagogu, psichologu, politiku, vadu, pavaldiniu ir pan. Toks vertinimas nustato labai aukštus standartus kariams, 
skiriamiems i vadovaujamas pareigas, o juos ne visada lengva išlaikyti, nes reikalavimai ką tik karinę mokymo ịstaigą baigusiam leitenantui yra mažesni, nei kylančiam karjeros laiptais karininkui, suteikiant aukštesnị laipsni ar perkeliant ji $\mathfrak{i}$ aukštesnes pareigas;

3. karinis vadovavimas ir visa karinè organizacija skirta veikti tiek taikos, tiek karo metu, todèl vadovavimo daugiapusiškumas yra neišvengiamybè, ir tai visiškai kitaip atsiskleidžia prasidejus karo veiksmams, kai chaosas, informacijos trūkumas, nuolatinis spaudimas, mirtys, sužeidimai ir daugybẻ kitų iššūkių verčia vadus ieškoti ne ịprastų, biurokratinių, o nestandartinių, labiausiai tinkamų toje ekstremalioje situacijoje sprendimų, kas ne taip būdinga civilinėms organizacijoms, ir, svarbiausia, niekas karinio vieneto vado neatleidžia nuo pareigos įvykdyti skirtą užduotị. Aišku, negalima pamiršti, kad civilinès organizacijos tam tikrais laikotarpiais taip pat išgyvena ịvairias krizes, bet iš kariuomenès vadovaujančio personalo karo metu reikalaujama kur kas didesnio žmogiškojo indèlio tiek intelektinio, tiek fizinio - neretai aukščiausieji karinių pajègų vadai vadovauja dešimtims tūkstančių pavaldinių ${ }^{1}$.

Remiantis šia karinio vadovavimo samprata, straipsnyje, taikant teksto analizès ir deskriptyvųji metodus, analizuojamos trys literatūros ir šaltinių, kurių pagrindu vèliau bus suformuluotos apibendrinamosios išvados, grupès. Esminis jo autoriaus tikslas - kad su karinio vadovavimo problemomis susipažinęs skaitytojas, vertindamas šiandienę situaciją Lietuvos kariuomenejje, galètų susidaryti aiškesnį vaizdą, kaip karinis vadovavimas traktuotas 1930-1940 m.

Šis laikotarpis pasirinktas dèl keleto priežasčių. Pirmiausia dèl to, kad tuo metu labai pagausejjo medžiagos vadovavimo tematika, antra - Lietuvos kariuomenèje po Nepriklausomybès kovų nusistovėjo aiškesnè organizacinè struktūra ir, trečia - sustiprèjo jaunoji karininkų karta, kurios dalis buvo parengta remiantis carinès Rusijos kariuomenès vadovavimo samprata, bet jau parveždavo naujų idejų iš Vakarų Europos.

Galiausiai šis straipsnis yra tarpdisciplininis, tinkantis tiek studijuojantiems vadybą, tiek istoriją, nes naudotuose šaltiniuose analizuojami reiškiniai dèl laikotarpio ypatumų yra sunkiai pamatuojami, daugiau atspindintys vadybinius (vadovavimo) nei istorinius dalykus. Atliekant ši

1 Keller, J. Military Leadership and Leaders. ENDC Proceeding, volume 19, 2014, p. 33-36. 
tyrimą nesiekiama atsakyti, kas tuo metu paveikè rašiusius vadovavimo tema (mintys, idejos ar asmenybės) ir ar karinis išsilavinimas, pvz., łgytas carinès Rusijos ar Vakarų šalių akademijose, turèjo įtakos jų karinio vadovavimo sampratai. Be to, svarbu pabrèžti, kad istoriografijos, analizuojančios karinio vadovavimo problematiką tarpukariu per vadovavimo mokslo, o ne per istorijos prizmę, nepavyko rasti.

\section{Pirmoji grupè: doktrininiai Lietuvos kariuomenès dokumentai}

XX a. 4-ojo dešimtmečio Lietuvos kariuomenès doktrininių leidinių buvo gausu. Vieni jų rengejjai aprašè ịvairius su buitimi, aprūpinimu, kasdiene tarnyba, kariniu rengimu daliniuose susijusius dalykus, kiti nustatè specialias procedūras, skirtas koviniams vienetams. Pirmiesiems vadovavimo klausimai nebuvo aktualūs, todèl jie nebus toliau nagrinèjami. Antruosiuose, priešingai, gana detaliai buvo aptarti ịvairūs vadovavimo aspektai. Kad galima būtų geriau issivaizduoti tuometę situaciją, neišvengiamai teks šiuos doktrininius leidinius gausiai cituoti, siekiant neiškreipti to, ką norejo pasakyti jų rengejjai. Vẻliau po kiekvieno jų aptarimo bus pateiktas trumpas vertinimas, pabrèžiantis esminius dalykus.

1924 m., 1931 m. (pakartotas 1924 m. leidimas ${ }^{2}$ ) Vidaus tarnybos statutas $^{3}$. Nepaisant to, kad šis statutas buvo išleistas iki mūsų nagrinejjamo laikotarpio pradžios, pažymètina, kad jis nepakeistas buvo perleistas 1931 m., todèl atitinka nustatytas chronologines ribas. Vèliau iki sovietinès okupacijos buvo išleistas ne vienas atnaujintas statutas, bet archyvuose ir bibliotekose išlikę jie ne ištisai, o tik kai kurios jų dalys, o naujausios versijos, kurioje būtų ir vadovavimui aktualios medžiagos, rasti nepavyko. Dèl šios priežasties toliau bus nagrinëjamas 1924 (1931 m.) leidimas. Vidaus tarnybos statute buvo aprašyta kariuomenès vidaus tvarka, karių pareigos ir pan., tad jị būtų galima lyginti su dabar galiojančia Lietuvos karine doktrina ${ }^{4}$ ir kitais tarnybą apibrèžiančiais statutais ir veiklos procedūrų dokumentais.

2 Informacija apie pakartotą $1924 \mathrm{~m}$. Vidaus tarnybos statuto leidimą $1931 \mathrm{~m}$. paimta iš Išeivijos lietuvių fondų [žr. 2019-01-31]. Preiga per internetą: http://www.archyvai.lt/lt/ iseivijos-fondai.html

3 Vidaus tarnybos statutas. Kaunas, 1924.

4 Lietuvos karinè doktrina D-LK-01. Vilnius, 2016. 
„IV. SKILTIS. Viršininkų pareigos. Bendrosios pareigos.

113. Viršininkas turi būti visur pavyzdys savo valdiniams.

114. Viršininkas laiko savo komandoj drausmę ir tvarką. Jis moko valdinius sąžiningai eiti tarnybos pareigas ir pats tokị pavyzdị duoda.

115. Jis turi būti teisingas, ramus, jo reikalavimai griežti. Jis duoda gyvumo, gero elgesio, ịstatymų ir viršininkų ịsakymų vykdymo pavyzdị.

116. Jis turi ikkvepti savo valdiniams pasišventimo tèvynei jausmą, pasiryžimą, klusnumą, drausmingumą, karių mandagumą, sumanumą; turi auklèti juose iniciatyvą, narsumą ir puolimo dvasią, tvirtą būdą, valią ir atkaklumą. Rūpinasi karo mokslą platinti, karišką ūpą, karišką ambiciją (savimeilę) ịkvejpti ir karžygiškumą kelti. <...>

119. Isakydamas savo valdiniams, leidžia jiems veikti duotųjų teisių ribose visiškai savarankiškai. <...>

121. Kiekvienas viršininkas turi tiksliai išmokti ir tvirtai žinoti visa, kas jo pareigoms yra privaloma. Neturi pamiršti, kad mokslo stoka mažina jo valdinių pasitikejjimą.

122. Viršininkas turi igyti savo valdinių pasitikèjimą ir pagarbą. Tam reikalui jis turi išdirbti savyje pareigos jausmą, tvirtą būdą, mokèjimą save valdyti, energiją ir iniciatyvą. $<\ldots>$

124. Kai viršininkas veikia savo iniciatyva, sprendimas visada turi visiškai atitikti vyresniojo viršininko bendram sumanymui. <...>

128. Jis ịvertina gabesniuosius valdinius, kad jie būtų parengti aukštesnèms vietoms. $<\ldots>$

130. Jis rūpinasi apie valdinių sveikatą ir jų reikalus; reikale būna patarèjas ir užtarẻjas; rūpinasi jų gerove ir stengiasi dorovejj nupuolusius pataisyti. “5

Vidaus tarnybos statuto esminès mintys, susijusios su vadų pareigų ir vadovavimo samprata, sukasi apie dvi aiškias ašis - vado savybes ir kompetenciją bei vado elgesị ir vadovavimo ypatumus. Pirmoji ašis apibrèžia neformaliąją vado asmenybès dalị, antroji skirta formaliems reikalavimams einamoms pareigoms apibrèžti.

Neformalioji asmenybès dalis apima vado žmogiškąsias savybes ir tam tikrus bendravimo iggūdžius, kurių reikia vadovaujant. Labiausiai išskiriamas asmeninio pozityvaus pavyzdžio leitmotyvas, kuris yra kertinis vado asmenybès akmuo, nes jis pavaldinių yra nuolatos stebimas, o jo

5 Vidaus tarnybos statutas. Kaunas, 1924, p. 28-31 
elgesys ir edukacinè, patriotinė veikla veikia juos kaip mokomoji priemoné, t. y. kariai ne tik gauna teorinių žinių, kaip turètų elgtis ir veikti, bet ir mato savo akimis, kad tai ịkūnija jų vadas. Dèl šios priežasties vadas privalo asmeniškai demonstruoti tai, ką skleidžia kitiems, ir pats atitikti kitiems keliamus reikalavimus. Kertinèmis vado asmeninėmis savybėmis laikomas teisingumas, narsa, iniciatyva, sąžiningumas, rūpestingumas ir kai kurios kitos. Dalis jų yra igimtos, dalis - igytos, bet, labai tikètina, kad, tinkamai rengiant vadus, daugelị tų savybių galima išugdyti, nes tai tiesiogiai susiję su asmeniniu pavyzdžiu, kas itin aktualu kasdienèje tarnyboje ir kritiškai svarbu mūšyje.

Formaliąją aši sudaro esminiai vadovavimo karinei organizacijai principai: įsakymų laikymasis ir jų davimas; savo pareigų ir darbo išmanymas, kas pasiekiama tik nuolat tobulinantis; karių vertinimas ir rūpinimasis jų gerove; karių mokymas ir patriotinis auklejimas; pamatuota iniciatyva veikti pagal aukštesniojo vado nustatytą kompetenciją, kad kuo geriau būtų igyvendintas pastarojo ketinimas, ir pan. Šio statuto formalioji karinio vadovavimo samprata taip pat iš dalies suponuoja mintị, kad, nepaisant taikomų minètų karinio vadovavimo principų, neformalioji vado asmenybès dalis yra iš tiesų svarbi. Neformalusis pamatas yra atspirties taškas, o jei jis yra silpnas, formalioji dalis nebetenka prasmès, nes jos principu igyvendinimas be stipraus, pozityvaus vado asmenybès pavyzdžio, be visų reikalingų savybių, kompetencijų ir elgesio standartų neduos siekiamo teigiamo rezultato. Dèl šios priežasties efektyvus karinis vadovavimas, tinkamai visapusiškai neparengus vado, greičiausiai neįmanomas.

Kario kalendorius 1931 metams $^{6}$. Šis leidinys buvo spausdinamas kiekvienais metais ir daugiau skirtas žemesniojo laipsnio puskarininkiams ir jaunesniesiems karininkams, tikètina, jog jis turejjo pasitarnauti ne tik kaip informacijos šaltinis kasdienėje tarnyboje, bet ir kaip patriotinè auklejjamoji medžiaga jaunajai karių kartai, nes, panašu, buvo ịteikiamas kiekvienam kariui asmeniškai ${ }^{7}$. Jame išvardytos visos svarbiausios šalies šventès, įskaitant ir religines, pateikiama trumpa Lietuvos valstybės ir

\footnotetext{
6 Kario kalendorius 1931 metams (365 dienos). Kaunas, 1930.

7 Kalendoriaus viename pirmųjų puslapių galima rasti vietą įrašyti savo vardui, asmens ir ginklo duomenims bei kitai kariui aktualiai informacijai, t. y. šis kalendorius turẻjo būti asmeninis pagalbininkas tarnyboje.
} 
kariuomenès istorija, aprašoma valstybès politinè sąranga ir pavaldumo hierarchija bei daug kitų eiliniam kariui aktualių dalykų nuo dujų karo iki arklių kaustymo: „Šio kalendoriaus tikslas, kaip sakėme, yra informacija - žinios apie mūsų valstybę ir, svarbiausia, apie jos apsaugą ir ginkluotąją jègą - kariuomenę, Šaulių sąjungą, dragūnus ir artimas organizacijas. Tos žinios reikalingos karo tarnyboje ir už jos. Todèl kalendorius tinka ir kareiviams, ir karininkams, ir atsarginiams, ir civilinėms ịstaigoms. " ${ }^{8} \mathrm{~Pa}-$ žymètina, kad nuo $1931 \mathrm{~m}$. kalendoriaus apimtis tik didejo, bet esminiai dalykai liko daugmaž tie patys.

Mums, kaip tyrejjams, Kario kalendorius aktualus dèl to, kad jame, nors ir nedoktrininiame leidinyje, labai paprastai apibrèžiama karinio vadovavimo tuometeje Lietuvos kariuomenejje grandinè, taigi, faktiškai atspindima kariné doktrina. Kadangi vadovavimo grandinè ir jos organizacija yra karinio vadovavimo sampratos dalis, ją taip pat privalu aptarti.

„Vadovybé. Visai kariuomenei ir kiekvienam vienetui vadovauja ju vadai ar viršininkai. <...> Krašto apsaugos ministeris yra aukščiausias po Respublikos Prezidento kariuomenès viršininkas. Jis sprendžia visus klausimus, kurie liečia kariuomenès organizaciją ir administraciją. <...> Vyriausiojo štabo viršininkas yra techniškas krašto apsaugos ministerio patarejas ir atsako už kariuomenès parengimą karui. Vyriausias štabas: Gedimino gt. 19. Vyr. štabo sudetis: generalinio štabo ir administracijos valdybos. Vyr. štabo viršininko priklauso: karo apygardų viršininkai, kariuomenès inspektorius, kavalerijos, aviacijos, karo technikos viršininkai, karo sanitarijos ir karo veterinarijos viršininkai ir šaulių sąungos viršininkas. Generalinio štabo valdybos viršininko priklauso: I, II, III, IV ir karo topografijos skyriai.

I (organizacijos ir mobilizacijos) skyrius rūpinasi kariuomenės organizacija ir mobilizacija (naujokų šaukimas, atsargon paleidimas, atsargos tvarkymas, ginkluotų pajėgų ir rezervų organizavimas).

II (informacijų) skyrius seka kitų valstybių kariuomenès organizaciją, apginklavimą ir mokymą.

III (operacijų) skyrius rengia krašto gynimo planus ir kariuomenei mokyti taisykles, programas, statutus ir vadovelius, tvarko ryšių tarnybą. Organizuoja kariuomenès manevrus, iškilmes.

IV (tarnybų) skyrius rūpinasi tiekimo, evakuacijos, etapų ir susisieki-

8 Kario kalendorius 1937 metams (365 dienos). Kaunas, 1936, p. 6. 
mo tarnybos reikalais $<\ldots>$ Administracijos valdyvos viršininkui priklauso: rikiuotès, pensijų, spaudos ir švietimo ir ūkio skyriai, kariuomenès archyvas, karo kapelionai ir kr. aps. m-jos kanceliarija. “9

1932 m. Stambesniu kariuomenès junginiu vadovavimo laikinieji dèsniai. Ṣ̌ laikinąji doktrininị dokumentą būtų galima laikyti vėlesnio leidimo ịvairių statutų atspirties tašku, nes jame išdèstytos mintys toliau plètojamos ne viename leidinyje. Jis apibrèžia vadų vaidmenị organizuojant karinius veiksmus su jiems pavaldžiais vienetais, vadovavimo hierarchiją, atsakomybės padalinimo principus ir kartu pateikia visą ankstesnę kariuomenės kovinių veiksmų organizavimo patirtį:

„4.Pasisekimą kautynèse laiduoja šie veiksmai:

kariuomenès dorinis parengimas, visų kovotojų tvirtas pasiryžimas nugalèti <...>

c) aiškus kautynių tikslas ir gera kautynių veiksmų organizacija, pagrịsta savo tiksliu kautynių priemonių ir gyvųjų jègų ypatybių bei aplinkybių ịvertinimu;

d) atsakomybės nebijojimas už drąsų nusprendimą<...>

9. Kautynèse kariuomenès vadovavimas užtikrinamas:

a) kariuomenès junginio taikos meto taktišku parengimu ir jo tobulinimu karo metu;

b) gera kariuomenès drausme;

c) nuolatiniu aplinkybių sekimu ir jų vertinimu drąsiais, be svyravimų priimtais ir aiškiai išreikštais sprendimais;

d) visų vadų savarankiškumu, tvirtu nusistatymu ịvykdyti gautus uždavinius ir sumaniu iniciatyvos pareiškimu;

e) ryškiu ir greitu vadovybės organų darbu ir nuolatiniu ryšių laiky$\mathrm{mu}$;

f) asmeniniu bendradarbiavimu $<\ldots .>$

11. Kautynių sudètingumas ir jų ịtempimas, kautynių tvarkos išblaškymas bei susmulkinimas apsunkina vadovavimą, bet tuo pačiu primygtinai reikalauja planingumo ir kautynių vadovavimo aiškumo. Tokiose sąlygose gyvas planingas vadovavimas ịvykdomas tik parodant visam kautynių sąstatui (dispozicijai) iki net eilinio kovotojo, didžiausią pasiaukojimą, griežčiausią drausmę bei iniciatyvą <...> vadas turi nuspręsti savo iniciatyva, išeidamas iš bendro junginio veikimo tikslo ir susidariu-

9 Kario kalendorius 1931 metams (365 dienos). Kaunas, 1930, p. 108-111. 
sių aplinkybių <...>

12. Junginio tinkamumą kautynėms vadovybė palaiko skiepydama:

a) tautinị ir valstybinị susipratimą, pasiryžimą pasiaukoti už krašto laisvę ir nepriklausomybę, karo tikslo aiškų supratimą, dvasios stiprybę ir vyriškumą;

b) viršininkų sveiką bendravimą su valdiniais, viduję vienybę, drausmę, pasitikejjimą savim ir vadovybe;

c) sklandų ir mokamą kautynių vadovavimą; laimèjimai labiausiai sustiprins pasitikejimą vadais ir dalių galią kautis $<\ldots>$ Viršininkas turi visais galimais būdais skiepyti valdiniams tikejjimą nugalèti, energiją, gyvumą darbe, kelti jų iniciatyvą ir pasiryžimą. "10

Čia pateiktose citatose pabrèžtos esminès sąvokos apima keletą pagrindinių formalaus doktrininio požiūrio ị vadovavimą aspektų:

1. Vadas, nesvarbu, kokia jo pozicija pagal pareigas karineje struktūroje, turi gebèti aiškiai suformuluoti visiems pavaldiniams pagrindinị tikslą. Tas tikslas turi būti toks aiškus ir suprantamas, kad net nutrūkus ryšiui su aukštesniąja vadaviete, pavaldūs vadai galètų imtis iniciatyvos ir suvokdami aukštesniojo vado ketinimą tęsti veiksmus šiam tikslui pasiekti.

2. Vadovavimas ir sprendimų prièmimo procesas turi būti aiškus ir greitas, kad būtų įmanoma spèti reaguoti ị nuolat besikeičiančią situaciją. Be to, vadui suteikta teisè prireikus savarankiškai priimti individualius sprendimus - tai dabar vadinama tiksliniu vadovavimu. Tikslinis vadovavimas $^{11}$ - tai vadovavimo būdas, kai centralizuotai priimti sprendimai pagal susiklosčiusią situaciją igyvendinami vadovaujantis jau žinomu aukštesniojo vado ketinimu, o sprendimo laisvẻ kovos veiksmų vietoje paliekama žemesniojo lygmens vadui su sąlyga, kad jis sugebės apie tai kuo greičiau informuoti kitus vadus tiek horizontalioje, tiek vertikalioje organizacinejje struktūroje ir kad jo veiksmai nesukels nereikalingos destrukcijos igyvendinant bendrą planą. Tikslinis vadovavimas neįmanomas be iniciatyvos ir drąsos priimti nestandartinius sprendimus, gebejjimo tinkamai ịvertinti susiklosčiusią situaciją.

3. Vadovas gali tikètis sẻkmès tik tada, kai jo organizacija gerai parengta, o jos struktūra aiški, subordinacijos kanalai žinomi, veiksmų

10 Stambesniu kariuomenès junginiu vadovavimo dessniai. Kaunas, 1932, p. 1-6.

11 Vadovavimas. LK vadovavimo doktrina D-LK-2018. Vilnius, 2018, p. 2-15, 4-2. 
laisve iš anksto apibrèžta, aprūpinimas užtikrintas. Tai taip pat vienas svarbiausių aspektų, ypač mūšio lauke, nes tik tinkamai sustyguota organizacija geba nukreipti visą savo potencialą iškeltam tikslui pasiekti, t. y. kai visi dirba koordinuotai ir kartu žino, ko tikètis iš kolegų.

4. Motyvaciniai aspektai, pradedant nuo asmeninio vado santykio su pavaldiniais ir baigiant reikalingų motyvacinių priemonių taikymu, taip pat itin svarbūs. Niekas taip nedemotyvuoja besikaunančių vienetų, kaip sutrikimai, atsiradę ne dèl priešo kaltès, o dèl to, kad organizacija prastai funkcionuoja (nesklandus maitinimas, aprūpinimas atsargomis ir pan.). Tikejjimas savo jègomis ir kad visi atliks tai, kas nuo ju priklauso, yra papildoma energija, kartais leidžianti atsilaikyti net sudètingiausiose situacijose. Kiekvienas vadas turi nepamiršti, kad kritinèse situacijose, ypač trūkstant reikalingų priemonių ir netekus dalies karių, motyvacija tampa ta vidine jèga, kuri veda ị priekị ir kartais leidžia neịtikètinai daug pasiekti.

„Visų kariuomenès kovotojų, nuo eilinio iki vyriausiojo vado, noras nugalèti yra pirmoji laimejjimo sąlyga $<\ldots>$ Noras nugalèti negali būti plačiai išplèstas, jei kareivio širdyje nèra pasitikèjimo savimi, savo kovos draugais ir savo vadais. <...> Vado vaidmuo kautynėse labai svarbus. Vadas - ar jis karininkas, ar puskarininkis - turi užsitarnauti valdinių pasitikejjimo ir pagarbos. <...> Vyraujanti viršininko savybè turi būti nuoširdus atsakomybės jausmas. <...> Jei žmonès žino, kad vadas gyvena dèl jų ir dalinasi su jais džiaugsmu ir nepasisekimais, jie mielai paaukoja visas jègas ir kantriai pakenčia nepasisekimus. <...>

61. Be gero kariško pasirengimo ir gerų kovotojo savybių, vadas turi būti gerbiamas ir kaip žmogus, už jo drąsą, už jo gerą ir drausmingą santykiavimą su valdiniais. Vadas turi būti savo valdinių patarèjas asmeniškuose ir kariškuose klausimuose. <...>

66. Kautynèse sprendžiamos reikšmès turi pačių vadų ir eilinių asmenų pavyzdys. Todèl visi vadai visada turi remti ir skatinti asmens sumanumo reiškinius ir pagirti kiekvieno kario narsumą puolamuose veiksmuose bei užsispyrimą ginamosiose kautynèse, o esant reikalui, savo pavyzdžiu bei dalyvavimu paveikti besikaunančią kariuomenę. "12

Ši ištrauka yra antra Stambesniu kariuomenès junginiu vadovavimo laikinujų dèsnių dalis, kurioje aprašomi vadovavimo principai ir demesys

12 Stambesniu kariuomenès junginių vadovavimo dèsniai. Kaunas, 1932, p. 26-27. 
sutelktas $\mathfrak{i}$ dalykus, kurie labiau susiję su asmeninėmis vado savybėmis, t. y. su svarbia neformaliąja dalimi - jo asmenybe, nuo kurios neretai priklauso, ar veikla bus sèkminga. Pirmiausia vadas turi būti toks, kad juo būtų galima pasitikèti, jo bendravimas, kad ir griežtas, - nuoširdus, o rūpestis - neapsimestinis. Vadas turi jausti savo pavaldinių pagarbą dèl to, kad yra tarp jų, o ne virš jų, kad savo asmeniniu pavyzdžiu įkvepia karius ir veda juos ị priekį, taigi, nèra tas, kuris slepiasi už nugarų. Galiausiai vado profesionalumas darbe aiškiai pastebimas, dèl to jis ir kaip žmogus, ir kaip karys užsitarnauja aplinkinių pagarbą ir igyja jų pasitikèjimą.

Šis vidinių asmeninių savybių rinkinys papildo formalųjị, nes siekiant efektyviai vadovauti, jų negalima atskirti, o visa kita yra karinio pasirengimo klausimas. Panaši tendencija pastebima ir kituose toliau pateiktuose doktrininiuose dokumentuose.

1937 m. Artilerijos statutas. A-51. Šis artilerijos statutas, kaip ir kiti kovos taktikos dokumentai, apibrèžè artilerijos naudojimo remiant sausumos padalinių vienetus specifiką. Skirtingai nuo péstininkų, artilerijos veiksmingumas priklausẻ nuo pirmųjų ugnies paramos užsakymų, t. y. artilerijos vienetai neturejjo galimybès veikti vieni pagal savo tiesioginę paskirtị be pėstininkų ar nekoordinuodami savo veiksmų su aviacija, todèl jų veikla privalèjo būti glaudžiai susijusi su tuo, kas vyksta fronto linijoje: „Šis statutas duoda artilerijos taktinio naudojimo rèmus įvairiose kautynėse ir jų ruožtuose. Jị taikant kiekvienu atskiru atveju, reikia siekti kuo didžiausio lankstumo ir tikslingumo, nuolat turint galvoje aplinkybes ir turimas priemones. <...> Artilerija veikia kitų ginklų rūšių, o ypač pèstininkų naudai. “13

„Kiekvienas artilerijos vadas rengia savo vienetą kautynėms ir jam vadovauja ịvairiose aplinkybėse. Kiek leidžia turimos priemonès ir aplinkybès, vadas rūpinasi suteikti savo vienetui kuo geriausias medžiagines, dvasines ir auklejjamąsias sąlygas. <...> Jis nepaliaujamai prižiūri ir tobulina savo vieneto techninị mokymą ir jo užgrūdinimą; jis tvirtai laikosi griežtos, bet teisingos drausmès. <...> Jis nuolat skiepija savo valdiniams tèvynès meilès, pareigos, garbès, vieningumo ir draugiškumo jausmus, pats visuomet būdamas jiems geru pavyzdžiu. <...>

74. Vadas igyja reikalingą pasitikejjimą savo būdo tvirtumu, aukšta dora, dalyko mokejjimu ir atsakomybès nevengimu. Jis turi būti ịstatymų

13 Artilerijos statutas. A-51. Kaunas, 1937, p. 1-3. 
gerbimo, sąžiningumo, klusnumo, narsumo, ryžtingumo ir pasiaukojimo pavyzdys. <...>

78. Aukštesnieji vadai, siekdami laimejjimo, naudoja turimas priemones ir dalinius, duodami pastariesiems reikalingus įsakymus $\langle\ldots>$, reikalauja iš žemesnių vadų:

a) nuolatinio budrumo;

b) sveikos iniciatyvos;

c) nesvyruojančio ryžtumo. <...>

$\mathrm{Ne}$ visuomet pavyksta padaryti visiškai tobulą ir be jokių trūkumų sprendimą. Tačiau griežtas ir energingas vykdymas gali išlyginti sprendimo spragas, tuo tarpu ir geriausias sprendimas, vykdomas lètai, be ryžtumo, gali duoti nekokias pasekmes. <...>

84. Kautynèse ryšiams sutrūkus, aplinkybėms visiškai pasikeitus arba negavus laiku reikalingų ísakymų, artilerijos vadas veikia savo iniciatyva. $<\ldots>$

82. Kiekvieno artilerijos vado pagrindinè pareiga kautynėse - vykdyti jam duodamus uždavinius, kuo tikslingiausiai panaudojant savąji ginklą. " ${ }^{4}$

Artilerijos statute, skirtingai nuo $1932 \mathrm{~m}$. junginių vadovavimo dèsnių, aiškiai neatskiriama, kas priklauso formaliajam ir neformaliajam vadovavimui, nes apie viską rašoma bendrai. Taigi, norint apibrèžti specifinius vienam ir kitam vadovavimui būdingus bruožus, citatose reikètu juos išskirti, nors statute jie neišskiriami.

Toliau pateikti esminiai tiek formaliosios, tiek neformaliosios vadovavimo pusès aspektai:

1. Vadas, anot statuto, yra ne tik asmuo, vertinamas už tam tikras būdo savybes, bet ir vadybininkas, administratorius, mokytojas, skirtingų ginklų rūšių veiksmų moderatorius, t. y. neužtenka tik vadovauti grupei žmonių - reikia turèti ịvairių kompetencijų, be kurių neįmanoma efektyviai tai daryti. Vadas privalo būti savo srities profesionalas, kartu nuolat tobulintis ne tik savo, bet ir kitose srityse, kuriose potencialiai gali tekti dirbti, - nuo péstininkų iki aviacijos.

2. Kaip ir pagal junginių vadovavimo dèsnius, vadas turi gebèti aiškiai suformuluoti savo pavaldiniams pagrindinị tikslą. Tikslo siekiama atliekant smulkesnes užduotis. Kaip ir tikslas, jos turi būti aiškios ir lengvai

14 Ten pat, p. 27-31. 
suprantamos, kad nutrūkus tiesioginiam ryšiui su vadaviete žemesnieji vadai galètų imtis iniciatyvos ir toliau vykdyti užduotị savo nuožiūra. Aišku, subordinacijos ir veiksmų koordinavimo klausimai vis vien išlieka aktualūs ir automatiškai nesuteikia vadui teisès veikti vienam.

3. Sprendimų prièmimo procesas taip pat iš dalies vyksta taikant tikslinio vadovavimo ${ }^{15}$ būdą, tad aiškiai pabrèžiama, kad sprendimo prièmimas yra viena svarbiausių vado kompetencijų. Siekiant, kad sprendimo prièmimo procesas būtų greitas, pabrèžiamos trys vadų savybès: budrumas, iniciatyva ir ryžtas. Budrumas leidžia laiku pastebèti priešo klaidas, savo vienetams galinčias kilti problemas ir tuo pasinaudoti. Šiomis galimybėmis pasinaudoti arba užkirsti kelią potencialioms problemoms neịmanoma be pagrịstos, greitai ir laiku parodytos iniciatyvos bei ryžto viso to imtis. Tai leidžia silpnesnèmis pajėgomis ịveikti didesnes ir galbūt geriau ginkluotas priešo pajègas, kurių vadai delsia priimti reikalingus sprendimus. Žinant potencialius tarpukario Lietuvos priešus ${ }^{16}$ ir jų vienetų dydi bei technines galimybes, greitis buvo labai svarbus veiksnys priimant tinkamus sprendimus.

4. Be visų čia paminètų kertinių dalykų, vadas taip pat privalo savo asmeniniu pavyzdžiu motyvuoti karius. Asmeninis pavyzdys, anot statuto, pirmiausia - tai geriausių vado būdo savybių ir kompetencijų demonstravimas. Paminètos kertinès savybès - narsumas, sąžiningumas, rūpestingumas ir ryžtingumas, taip pat teisingumas ir pagarba pavaldiniams, profesionalumas sudaro darnią visumą - pavyzdinio vado paveikslą.

5. Paskutinis statuto pabrèžiamas dalykas - komandiškumas. Vienas svarbiausių vado darbų rengiant dalinị kovos veiksmams yra komandos formavimas. Akcentuojama vieningumo ir draugiškumo, intensyvaus karinio rengimo svarba. Šie dalykai veikia kaip itin vienijantys veiksniai, nes kovos sąlygomis prastai susiformavęs vienetas labai greitai gali pakrikti ir neatlikti jam skirtos užduoties. Geros komandos karių neformalūs ryšiai tiek tarpusavyje, tiek su vadais padeda psichologiškai išgyventi sunkias akimirkas ir veikia kaip papildomas motyvuojantis veiksnys labiau stengtis, palaikyti vieniems kitus, kariniame vienete kurti pasitikejji-

15 Vadovavimas. LK vadovavimo doktrina D-LK-2018. Vilnius, 2018, p. 2-15, 4-2.

16 JOKUBAUSKAS, V. „Mažujų kariuomeniu“" galia ir paramilitarizmas. Tarpukario Lietuvos atvejis. Klaipèda, 2014, p. 437. 
mu grịstą atmosferą ${ }^{17}$.

1939 m. Péstininku statutas. P-51. Pèstininkų statutas buvo skirtas taktinei ir operatyvinei sausumos kovinių padalinių veiklai, doktrininiams reikalavimams planuojant ir vykdant kovos veiksmus, vadų atsakomybei, veiksmų gairèms, sąveikai su kitomis ginklų rūšimis ir pan. apibrèžti: „Visi pėstininkų vadai šį statutą, kaip savąjį, turi mokèti kuo geriausiai. Bet ir visų kitų ginklų rūšių vadai turi jo, kaip pagrindinio statuto, taisykles taip gerai suvokti, kad galètų kaip reikiant bendradarbiauti su pèstininkais. " 18

Taigi, Pėstininkų statutas - iš visų Lietuvos kariuomenès statutų svarbiausias, nes sausumos pajègos, tiesiogiai remiamos oro pajėgų, tarpukariu buvo pagrindinè ašis, apie kurią sukosi visi kiti kariuomenės vienetai ${ }^{19}$.

„Kariuomenès vieneto vertė labai daug priklauso nuo jų vadų vertès. $<\ldots>$ Būdo privalumų tarpe pirmiausia reikia skirti atsakomybès nebijojimą. Vadas turi būti teisingas, korektingas, prielankus valdiniams, lojalus savo viršininkui. <...> Vadas turi atsiminti, kad kautynėse už vis blogiausiai valdinių dvasią veikia beprasmès aukos. Todèl čia jis turi ypač žiūrèti, kad jo ir jo priklausomų vadų veiksmai būtų gerai apgalvoti, teisingi, suderinti su tikrove.

163. Vadovauti - reiškia numatyti, įsakyti ir žiūrèti ịsakymų vykdymo. Bet kuris vadas kautynèse turi visada:

a) gerai atsiminti gautąji uždavinį;

b) mokèti spręsti;

c) mokèti sprendimą išreikšti aiškiu ịsakymu ir paskirstyti uždavinius tarp valdinių;

d) duoti valdiniams tinkamų priemonių ir užtikrinti jiems reikalingą ugnies paramą; <...>

g) rūpintis savo dalinio saugumu; <...>

j) visais atvejais kuo energingiausiai iki pat galo vykdyti savo uždavinị.

164. Gerai parengtame ir ị darbą ịtrauktame sveikos dvasios vienete visi pareigūnai turi sveikos iniciatyvos, moka savo pareigas ir tinkamai jas eina, nesikišdami nei ị savo valdinių, nei ị viršininkų pareigas. <...>

17 MCGINN, D. What Companies Can Learn from Military Teams. Harvard Business Review [žr. 2019-01-29]. Prieiga per internetą: https://hbr.org/2015/08/what-companiescan-learn-from-military-teams

18 Péstininku statutas. P-51. Kaunas, 1939, p. 1. 
166. Pėstininkus labiau nei kitas ginklų rūšis veikia kautynių lauko ìspūdžiai. Sugebėti greitai kintančiose îspūdingose aplinkybėse išlaikyti nepalaužtą pėstininkų dvasią yra pagrindinė ir sunkiausiai ịvykdoma péstininkų vado pareiga.

Kariuomenès vieneto dvasinis patvarumas priklauso nuo vado įtakos, jo rūpestingumo valdiniais, jų būdo pažinimo ir vado asmeninio pavyzdžio. <...> Vadas visada visų pirma rūpinasi ne savo asmens, bet savo valdinių gerove. Jis veikia karių širdis ir protą, visur ir visada pabrèždamas, kad kare tèvynès likimas priklauso nuo karių pasiryžimo kantriai kęsti visus karo vargus ir aukoti savo gyvybę. <...> Vado valios, narsumo ir šaltakraujiškumo veikiamas kareivis yra pasiryžęs bet kurioms aukoms. “20

„Mūšyje ar kautynèse mažesnių dalinių vadai gali susivokti tik labai nežymioje kautynių lauko dalelèje. Jie kaunasi dažniausiai nežinodami, kas iš viso yra pasiekta. Tačiau bendra pergalè pagrindinai priklauso nuo asmeninio žemesnių vadų atsparumo. Tariamoji beviltinè padètis dažnai atitaisoma žemesniųjų péstininkų vadų pasiryžimu ir jų drąsia iniciatyva." ${ }^{21}$

Analizuojant Pėstininkų statuto kertines citatas galima pastebèti labai panašią tendenciją, kuri kartojasi ir kituose anksčiau minètuose šio skyriaus dokumentuose. Išlaikoma tokia pat tendencija kaip ir Artilerijos statute, kai formalusis ir neformalusis vadovavimas aprašomi kartu, ne vieno iš jų neišskiriant. Be to, Pėstininkų statute išskiriamos ir vado, kaip vadybininko, savybès, kurių reikia efektyviam vieneto funkcionavimui užtikrinti.

Toliau pateikiami pagrindiniai šio statuto aspektai:

1. Užduotys ir sprendimo prièmimo procesas. Užduotys (statutuose - uždaviniai) yra karinės veiklos pagrindas. Jas ịvykdyti, ypač mūšyje, sunku, bet tam dalinys ruošiasi, dèl to treniruojasi ir sutelkia visas savo fizines ir dvasines jègas, kai to labiausiai reikia. Aišku, kovos metu retai jas atlikti yra paprasta ir tiesiogiai nesusidūrus su priešu, dèl ko dažniausia neišvengiama aukų. Tokioje situacijoje itin svarbu vadui teisingai ir adekvačiai užduotị ịvertinti ir po to laiku, greitai ir iniciatyviai priimti tinkamą sprendimą, kartu atlikti formaliojo vadovavimo procedūrą duoti ịsakyma pavaldiems vienetams. Issakymas formaliąa prasme yra

\footnotetext{
20 Péstininku statutas. P-51. Kaunas, 1939, p. 78-81.

21 Ten pat, p. 5.
} 
aiškus veiksmas, įforminamas rašytiniu dokumentu. Bet yra ir kita įsakymo pusè - tai pavaldiniams suprantamas jo turinys. Taigi, vadui neužtenka vien pačiam suvokti gautą ịsakymą, reikia gebėti ji performuluoti taip, kad jam ịgyvendinti būtų pasirinkti tinkamiausi pavaldūs vienetai ir jiems perteiktos detalizuoto įsakymo dalys, paliekant laisvès individualiam veikimui (tikslinio vadovavimo principas). Nuo šio sudètingo proceso efektyvumo priklauso, ar bus įmanoma pasiekti pozityvių rezultatų.

2. Valia kautis. Šiuo terminu apibrèžiamas karinio vieneto ir jo karių nusiteikimas, kuris lemia, bus nuspręsta kautis ar ne. Nèra konkrečios formulès, kuri leistų atsakyti, ar dalinys kausis, ar vengs mūšio, pvz., net ir prastai parengtas vienetas, ịspaustas ị kampą, gali atkakliai kautis, nors pirminis to vieneto vertinimas liudijo galimą greitą pasidavimą. Kariai gali kautis be vado, gero aprūpinimo, be pakankamos ginkluotès - vien tik sutelkę valią kautis. Ir priešingai, net ir geriausiai aprūpinti daliniai, vadovaujami puikiai parengtų ir patyrusių vadų, ginkluoti patikimais ginklais, gali būti nieko verti, jei neturès valios kautis, kuri Pèstininkų statute apibrèžta kaip karinio vieneto dvasia, už kurios puoselèjimą vadas yra tiesiogiai atsakingas.

3. Galiausiai, kaip ir kituose doktrininiuose dokumentuose, vèl minimi tokie dalykai kaip asmeninis vado pavyzdys, motyvacinės priemonès ir pabrèžiami vadui reikalingi organizaciniai (vadybininko) gebejimai, kad būtų užtikrintas dalinio funkcionalumas.

Apibendrinant galima konstatuoti, kad doktrininiai dokumentai turi daug bendrumų. Pagrindinès mintys juose daugmaž panašios. Ryškèja tendencija, kad doktrininių dokumentų karinio vadovavimo formuluotès lètai kito, kol galutinai nusistovejjo XX a. 4-ojo dešimtmečio pabaigoje.

\section{Antroji grupè: karinio rengimo ir mokymo dokumentai}

$\mathrm{XX}$ a. 4-ojo dešimtmečio Lietuvos kariuomenès karinio rengimo ir mokymo dokumentus sudarè vadovèliai, paskaitų medžiaga, mokymo programos ir pan. Vertinant karinio rengimo ir mokymo dokumentus svarbu nepamiršti, kad dauguma jų kaip mokomoji medžiaga buvo kuriami remiantis jau egzistuojančiais pirmosios grupès doktrininiais dokumentais, pvz., statutais, kita dalis buvo dèstytojų asmeniškai parengta medžiaga, kuri ne visada likdavo mokymo institucijose, nes kai kurie ju buvo pakviesti dèstyti iš civilinių mokslo ịstaigų. Tai pastebèta Lietuvos 
centriniame valstybès archyve tiriant karinių mokslo įstaigų civilinės pakraipos mokymo programas.

Taip pat mus itin domino, kiek tikslinių valandų buvo skirta su vadovavimu susijusiems dalykams. Vadovavimo teorijos buvo mokoma per pedagogikos, psichologijos ir istorijos paskaitas, visa kita turejjo būti išmokstama tiesiogiai vadovaujant.

1932 m. Generalinio štabo kursų Karo istorijos įvadas. Šiame vadovèlyje aprašyti esminiai karybos principai, kuriuos tuo metu privalejo perprasti kursų studentai. Jame rašoma, kad „jėgų visuma, kuriomis disponuoja kariaujančioji pusè, gali būti taip suskirstyta:

1. Medžiaginès jègos, ūmai pavartotinos.

2. Moralinès jègos.

3. Tūnančios moralinès ir materialinès jègos, ūmai nepavartotinos $<\ldots>$

Kariaujančio moralinès jègos pareina nuo:

a) tautos dvasinio būvio.

b) vidinès ginkluotų jègų vertybès.

c) Kariuomenę valdančių viršininkų vertybės <...>

Ypatingas ir svarbus vaidmuo moralinèse jègose tenka kariuomenès vadų moralinei vertei, vadų būdui, mokslui, tgudimui, menui ir jų individualioms moralinėms savybėms. Vadovybès, o ypač vyriausiojo vado vertè padidina visas jègas, ir tai gali būti labai žymus priedas. Vyriausiasis vadas, kaip ir visi kiti kariai, o net ir daugiau už juos, turi garbès prievolių. " 22

Šiame istorijos kurse pabrèžiama, kad nuo vadų priklauso labai daug. Vien tik geras karinis parengimas, aprūpinimas ir pan. negarantuoja sèkmės. Pateikiama nemažai istorinių îvykių pavyzdžių, kai pripažinti vadai, kaip, pavyzdžiui, Napoleonas I, vertino stiprius ir niekino kvailus vadus, kurie, neturėdami net reikalingiausių dalykų, buvo pasiryžę pradėti karus, stoti ị mūšius. Vadų reikšmė istoriniame kontekste traktuota kaip itin svarbi, nes nuo to iš dalies priklausė galutinis mūšio rezultatas, ypač pabrèžiant moralinę vadovavimo pusę. Deja, detalesnio kursų medžiagos aprašymo rasti nepavyko, kad būtų galima padaryti išsamesnes išvadas, bet reikia pabrèžti, kad istoriniame kontekste tinkamo vadovavimo svarba labai akcentuota.

22 GERULAITIS, Z., generolas leit. Karo istorijos įvadas. Kaunas, 1932, p. 6-9. 
Mokymo ìstaigu, daliniu karinio rengimo programos, planai ir destyti dalykai. Lietuvos centriniame valstybės archyve analizuojant ịvairias karinio rengimo programas ir planus pastebèta, kad tiek kariniuose vienetuose, tiek mokymo ịstaigose aiškiai išskirtų karinio vadovavimo paskaitų nebuvo numatyta. Labai tikètina, kad ši problema susijusi su suvokimu, kad geriausia vadovauti mokytis praktiškai, tiesiogiai dalyvaujant vadovavimo procesuose, ypač kalbant apie rengimą daliniuose, nustatyta tvarka, pvz.: „Šie pratimai bus atliekami lauke. Šiems pratimams pratimo vadovas pateikia pratimo temą, pèst. dalies /dalinio/ vado sumanymą ir artil. vadui reikalavimą dèl artil. veiksmų, po to grupès vadas su štabu turi pradèti darbą, duodamas siūlymą, ỉsakymą ir t. t. Ši grupés vado ir jo štabo darbą pratimo vadovas stebi nekliudydamas vykdyti. Vèliau pratimo vadovas stebi panašiai bent vienos baterijos vado ir jo vadovavimo būrio vado darbą ir tik pratimui pasibaigus, nagrinejjimo formoje pastebi, kas, jo nuomone, buvo gerai padaryta ir kas blogai padaryta, nurodydamas, kaip turèjo būti padaryta. ${ }^{\text {“23 }}$

Aišku, klasejje vykdavo teorinis rengimas (greičiausiai - pirmosios grupès doktrininių dokumentų pagrindu). Bet iš ịvairių atsiliepimų galima susidaryti įspūdị, kad vadovavimo spragų būta jau pačioje Karo mokykloje: „Karo mokykloje igauna kai kuriuos ịpročius, mano nuomone, nesuderinamus su drausmės dvasia ir žmonėse praktikuojamomis mandagumo taisyklèmis $<\ldots$. be to, būtų gera, kad daugiau būtų kreipiama dèmesio ị būsimojo karininko sugebẻjimą komanduoti/mokejjimą balsą valdyti ir laikytis komanduojant, sugebejimą pasirinkti pastabos formą ir pan. ${ }^{\text {"24 }}$

Vadovavimo nesklandumų pastebèta ir per didžiąsias pratybas: „Štabas ilgai delsẻ su atidavimu rengiamų ísakymų, ko pasekoje artilerija pavelavo išsidèstyti IX. 16 d. puolimui. Divizijos vadas ir visas štabas IX.15-16 d. naktị visai nemiegojo. Štabo darbą reikètų taip sutvarkyti, kad pareigūnai pakaitomis gautų pailsèti. Dirbant be poilsio, kaip vado taip štabo darbininkų vertè menka. Divizijos štabe visai nesirūpinta štabo pareigūnų mityba. ${ }^{\text {25 }}$

23 II pėstininkų divizijos štabo I skyriaus byla Nr. 2, 1939 m. Karininkų mokymas. LCVA, f. 510, ap. 1, b. 390, 1. 223.

24 Ten pat, b. 339, 1. 34 .

25 Ten pat, 1. 157. 
Galima būtų teigti, kad tai - tik vienam kariniam vienetui tam tikru laikotarpiu kilę iššūkiai, kurie galejo būti susiję su tuo metu vadovavusiu personalu, bet panašios tendencijos pastebimos ir kituose daliniuose. Be to, karinių vienetų mokymo programose ir planuose dominuoja tokie dèstomieji dalykai kaip taktikos teorija ir praktika, šaudyba, ginklai, ryšiai, topografija, rikiuotès užsièmimai, jodinèjimas, karinès literatūros, ìskaitant užsienio spaudą, apžvalga ir jiems skiriama daugiausia dèmesio, o, pvz., būrio vado pareigoms pagal Vidaus tarnybos statutą per savaitę palikta tik 1 valanda ${ }^{26}$. Kariniame rengime prioritetas skiriamas taktikos pratimams, kovinių veiksmų treniravimui, nurodyta „karo žaidimuose ir lauko pratimuose aplinkybes imti paprastesnes, kad būtų galima patobulinti vadų darbo metodą ir štabų veiklą, o lauko pratimuose būtų ịprasta teisingai vertinti vietove $<\ldots>$ puskarininkių mokymą tvarkyti pulkų

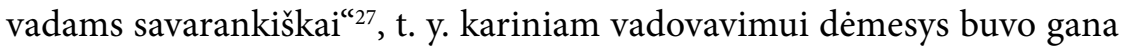
menkas.

Šių problemų, kad ir labai siaurai aprašytų, labai tikètina, šaknys yra už karinių vienetų ribų. Pavyzdžiui, analizuojant Vytauto Didžiojo karininkų kursų 1938 metų 4 savaičių mokymo planą pèstininkų batalionų vadams, pastebima, kad iš dėstomųjų dalykų karinio vadovavimo mokymui neskirta nè vienos tikslinès valandos, kai pėstininkų taktikai numatyta 60 val., artilerijai - 14 val., kavalerijai - 4 val. ir pan. ${ }^{28}$ Panaši tendencija, nepaisant deklaruojamų mokymo tikslų - „sugebėti sèkmingai vadovauti visų ginklų rūšių stambesniam daliniui ar junginiui, t. y. būti pilna to žodžio prasme vadu <...> siekiant užsibrèžtojo tikslo, Generalinio štabo skyriuje vyraus kariniai mokslo dalykai, kurie daugiausia remsis tikrųjų karo aplinkybių vadovavimo principais“, - pastebima tos pačios karo mokyklos Generalinio štabo skyriaus mokymo plane ${ }^{29}$. Iš 31 dèstomojo dalyko, kurio paskaitose nagrinejjamas ir karinis vadovavimas, aprašymų matyti, kad galima iš dalies su tuo susieti tik karo istoriją

26 II pėstininkų divizijos štabo I skyriaus byla Nr. 2, 1939 m. Karininkų mokymas. LCVA, f. 510 , ap. 1, b. $390,1.112$.

27 Ten pat, 1. 205.

28 Vytauto Didžiojo karo mokykla. Pėstininkų batalionų vadų keturių savaičių kursų mokymo planas. 1938 m. LCVA, f. 1481, ap. 1, b. 153, 1. 6.

29 Vytauto Didžiojo karo mokykla. Generalinio štabo skyriaus mokymo planas. $1939 \mathrm{~m}$. LCVA, f. 1481, ap. 1, b. 238, 1. 3. 
(100 val.), eksperimentinę ir karo psichologiją (25 val. - minėtinos temos „Karininkų pašaukimas ir jų psichologinè atranka“, „Bendrieji karybos psichologijos bruožai“, „Didžiųjų karo vadų psichologija“) ir karo žaidimus $(29 \mathrm{val} .)^{30}$. İdomiausia, kad tikrinant žinias psichologija iš viso nèra vertinama, nes ši kursą užteko tik išklausyti ${ }^{31}$. Dar svarbiau pabrèžti, kad tarp 1935 m. Generalinio štabo kursų mokymo programos ir 1939 m. programos esminių skirtumų nèra, todèl darytina išvada, kad kursų organizatoriai teorinio vadovavimo nesureikšmino, tikèdamiesi, kad šių žinių kariai igis savarankiškai ${ }^{32}$.

Minètus su vadovavimo mokymu susijusius trūkumus būtų galima kritikuoti motyvuojant tuo, kad karininkai turejo karinio vadovavimo pagrindus igyti dar prieš jiems suteikiant pirmąj karininko laipsnị, bet akivaizdu, jog tam nebuvo skiriama dèmesio. Vienas iš pavyzdžių galètų būti 1930 m. Kariūnų-aspirantų mokymo planas, kuriame numatyta daug taktikos, ginklų naudojimo, statutų, teisès ir pan. dèstomųjų dalykų, o vadovavimo teorijai beveik neskirta laiko, tiesa, 8 val. paliktos pokalbiams drausmès, psichologijos, auklejjimo ir panašiais klausimais ${ }^{33}$.

Galiausiai, nagrinejjant ịvairių kitų karinių mokymo įstaigų mokymo planus, pastebèta, kad i 1937-1940 m. Karo aviacijos mokyklos Puskarininkių klasės Lakūnų skyriaus mokymo planą įtrauktas dėstomasis dalykas, kurio kitose mokymo įstaigose nebuvo, - dorovès mokymas ${ }^{34}$. Jis vienintelis, nors jam buvo skirta tik 20 val., iki šiol analizuotų dėstomųjų dalykų, numatytų ịvairiose programose ir planuose, paliečia ne tik religijos, bet ir patriotizmo, kario autoriteto, asmeninių savybių, tokių kaip sąžiningumas, doras elgesys ir pan., klausimus. Dorovès mokymą galima būtų sieti su doktrininiuose dokumentuose minimais svarbiais vadovavimui vado asmenybés aspektais, tik vis dar neaišku, kodėl tokio ar panašaus dalyko kitose mokymo ịstaigose nebuvo arba bent jau programų

\footnotetext{
30 Ten pat, 1. 12 .

31 Ten pat, 1. 77.

32 Vytauto Didžiojo karo mokykla. Generalinio štabo kursai. 1935 m. LCVA, f. 1481, ap. 1, b. 84, 1. 13 .

33 Krašto apsaugos ministerija. Kariūnai-aspirantai $1930 \mathrm{~m}$. Mokymo byla. LCVA, f. 1451 , ap. 2 , b. $24,1.1$.

34 Karo aviacijos mokykla. Puskarininkių klasès mokymo planas. 1937-40 m. LCVA, f. 1451 , ap. 5 , b. $38,1.29$.
} 
aprašymuose jis nepaminètas.

$1939 \mathrm{~m}$. Karo pedagogika ${ }^{35}$. Šis leidinys yra skirtas to meto karo pedagogikos, karių auklejimo ir mokymo sampratai apibrèžti. Analizuojant ìvadą pastebima, kad Karo pedagogikos autorius ieško sistemiškumo. Jo teiginiai grindžiami pamatuojamais pavyzdžiais, bandant užpildyti vadovavimo sampratos teorinių idejų vakuumą, teikiant pirmenybę praktikai, o ne teorijai. Ši tendencija, nepaisant, kad kalbama ir apie teorinio mokymo ir ugdymo svarbą, matyti visame leidinyje: „Visa tai, kuo auklètojas veikia auklètini, kad atsiektų ugdymo tikslą, vadinasi ugdymo priemonemis. Auklètini galima veikti žodžiu ir darbu. Veikimas žodžiu bus pamokymas, patarimas, įsakymas ir uždraudimas, gi veikimas darbu - pratinimas, pavyzdys, priežiūra <...> prie ugdymo priemonių dažnai priskiriamas ir mokymas, kuris taip pat turi atitinkamų priemonių: knygų, vadovèlių, rašomųjų priemonių ir t. t." ${ }^{36}$

Pasak Karo pedagogikos autoriaus, esminis praktinis auklejamasis darbas yra vado (viršininko) svarbiausia pareiga: „Pareigu jausmas, viršininkų elgesys ir mokejjimas paimti $\mathfrak{i}$ „,rankas“ savo valdinius, ir tų valdinių kultūringumas - yra lygiai svarbios sąlygos ir turi pagrindinę reikšmę nugalint kautynèse baimę. “ ${ }^{37} \mathrm{O}$ teorinis pagrindas yra tik remiantysis dalykas: „Viršininkas-instruktorius turi stengtis arčiau ieiti i mokomų ir auklèjamų karių gyvenimą, o nepasitenkinti vien tik susidūrimu su kareiviais užsièmimų metu. Viršininkas /ir mokytojas instruktorius/ kariuomenèje yra svarbiausias auklejimo asmuo. Instruktorius turi gerai žinoti, kaip jis turi elgtis, ko jis turi siekti, kad sudaryti tinkamas auklejimo sąlygas." ${ }^{38}$

Karo pedagogikoje taip pat apibūdinami vadų (viršininkų) įsipareigojimai savo kariams, be kurių neįmanomas sėkmingas auklejamasis darbas, ir čia vèl pirmumas teikiamas praktiniams dalykams:

- vadų teisingumui arba teisingam elgesiui su pavaldiniais, kuris pasireiškia vienodu ịsakymų be išlygų taikymu visiems (įskaitant tiek teigiamus, tiek neigiamus atvejus), teisingu pavaldinių vertinimu atsižvelgiant i juc gabumus, pagarba kario vertei, atsakomybès nevengimu, net jei ir

\footnotetext{
35 ABARAVIČIUS, K., plk. leit. Karo pedagogika. Kaunas, 1939.

36 Ten pat, p. 2.

37 Ten pat, p. 5.

38 Ten pat, p. 7.
} 
duotas įsakymas buvo prastos kokybės;

- pavaldinių pasitikejjimu, pagarba ir meile, kurie užsitarnaujami tik rodant pozityvų asmeninị pavyzdị;

- veikla rūpinantis karių sveikata, gerove ir sėkme ${ }^{39}$.

Galiausiai Karo pedagogika pateikia vadovavimo apibrèžimą: „Vadovavimas - tai veikimas ị valdinių protą, jausmus ir valią, norint juos padaryti drausmingais. “" Vadovavimas vertinamas kaip subjektyvi auklèjimo priemoné, paremta asmeniniu pavyzdžiu, bet kartu turinti ir tam tikrų galių naudojantis prievartos mechanizmu (pvz., nuobaudomis) ugdyti karius taip, kaip labiausiai to reikia. Geriausia, jei įmanoma, karius auklèti draugiškoje atmosferoje, kur vadovavimo ịsakymai būtų kaip jų pastangų nukreipimo forma tikslui pasiekti, o karių paklusnus ir drausmingas jų vykdymas - natūralus atsakas: „Kad įsakymas turètų auklejjančios reikšmès, turi turèti sekančius privalumus:

1. Turi būti drąsus, be abejojimų, svyravimų ir baimès $<\ldots>$

2. Turi būti aiškus ir tikslus, kaip turiniu, taip ir tikslu $<\ldots>$

3. Isakymas turi būti trumpas ir energingas $<\ldots>$

4. Issakymas turi būti ịvykdomas $<\ldots>$

5. Turi būti nuoseklus <...>

6. Isakymas turi būti ramus $<\ldots>$

7. Isakymas turi būti stiprus ir griežtas $<\ldots>$

8. Turi būti suderintas su kareivių priedermių dvasias $<\ldots>$

Tokiais issakymais veikiant, galima duoti valdiniams suprasti, kiek kiekvienas viršininko ịsakymas yra reikalingas ir šventas dalykas, ir i kiekvieną ịsakymą valdiniai žiūrès su pasitikèjimu <...> Kontrolè sudaro vieną ir tiksliausią priemonę valdiniams drausminti, arba disciplinuoti. Isakymai pildomi tiek, kiek jie kontroliuojami <...> Kad kontrolė atneštu reikalingos naudos, reikalinga laikytis šių taisyklių:

1. Kontrolè turi būti nuolatinè $<\ldots>$

2. Kontrolè turi būti tikra $<\ldots$. “"41

Iš čia pateiktų citatų matyti, kad vadovavimas suvokiamas kaip ne tik formaliųjų, bet ir neformaliųjų bruožų turintis procesas. Toks nusistatymas leidžia suprasti ịsakymus ne tik kaip vadovavimo igyvendinimo

\footnotetext{
39 Ten pat, p. 12-15.

40 Ten pat, p. 15.

41 ABARAVIČIUS, K., plk. leit. Karo pedagogika. Kaunas, 1939, p. 16-17.
} 
ir kontrolès ịrankį, bet ir kaip svarbų mąstymo procesą, nes ịsakymas neduodamas šiaip sau. İsakymas rengiamas vadovaujantis ịvairiais kriterijais ir atsižvelgiant ị personalą, kuriam jis duodamas, jo pasirengimo lygit, gebejjimus ir pan. İsakymas yra vertinamas taip pat atsižvelgiant $\mathfrak{i}$ galimybę vykdyti jo kontrolę, kadangi be kontrolès įsakymo veiksmingumas abejotinas, o įsakymas be aiškios minties, kaip reikès jo igyvendinimą kontroliuoti, labai dažnai vertinamas kaip pasmerktas nuo pat pradžių. Vadovavimo prasme įsakymai tušti, jeigu juos duodantis vadas pats nepasiruošęs jų vykdyti.

Galiausiai iš visų iki šiol analizuotų tarpukario leidinių Karo pedagogika išsamiausiai ir sistemiškai mėgina aptarti vadovavimą. Kadangi vadovavimas tuo metu nebuvo laikomas atskira disciplina, Karo pedagogikoje jis analizuotas kaip auklejjimo ir mokymo priemoné. Dél šios priežasties darytina prielaida, kad čia ir yra esmine takoskyra tarp doktrinose pateiktų „nuomonių“, kas yra karinis vadovavimas, ir taip mèginta Karo pedagogikoje sukurti formalųji vadovavimo pagrindą, paremtą konstruktyvia analize, kas suteikia jai moksliniu požiūriu gerokai didesnị lyginamąji svorị. Galima būtų teigti, kad šis plk. ltn. Kazio Aparavičiaus leidinys buvo pirmasis iš nagrinejamojo laikotarpio leidinių, kuriuo remiantis buvo kuriama teorine karinio vadovavimo sampratos bazé.

1940 m. Karinio auklejimo paskaitos ${ }^{42}$. Tai dvi knygos (nors planuota išleisti penkias), skirtos padèti ugdyti karius. Jos aprèpia daug ìvairių temų, tiesiogiai nesusijusių su kariniu rengimu ir skirtų visapusiškai šviesti. Temos labai įvairios, todèl skyriai tarpusavyje dažniausiai neturi jokio ryšio, ką rodo, pvz., skyrių pavadinimai „Baudžiava Lietuvoje“ ir „Priešo propaganda karių tarpe“, nors pratarmèje pabrèžta, kad „laukiamų vaisių galima pasiekti tik tada, kai kareivis savo tarnybos metu gaus progos išklausyti sisteminị paskaitų kursą. Toks kursas, be abejo, turès sudaryti tam tikrą kareivio pažiūrą ir ideologiją" ${ }^{33}$. Dėl to ir vadų (vadovavimo) tema, išanalizuota atskirai, be jokios tiesioginés aliuzijos ị kitus skyrius, galètų būti vertinama kaip vienas pirmųjų mėginimų toliau tęsti 1939 m. Karo pedagogikos padiktuotą kursą vadovavimo tema. Be to, pažymėtina, kad šiame leidinyje vadovavimo ir vadų vaidmens klausimai dažniausiai nagrinėjami kariavimo ir kautynių kontekste.

${ }^{42}$ Karinio auklejjimo paskaitos. I ir II knygos. Kaunas, 1940.
43 Karinio auklejimo paskaitos. I knyga. Kaunas, 1940, p. 3. 
Vadovavimo analizė II knygoje pradedama nuo paaiškinimo, kas yra ir kam reikalinga karinè hierarchija, koks jos tikslas ir kaip sunku vadovauti daug skirtingų ginklų rūšių, išsiméčiusių dideliam plote, karių grupèms, kai tarp tam tikrų hierarchinių lygių gali net nebūti tiesioginio balsinio ryšio. Dèl to: „Sklandaus vadovavimo galima pasiekti tik gerai parengiant vadus, štabų ir tarnybų pareigūnus ir taikos metu išmokius juos tarpusavyje bendradarbiauti. " ${ }^{44}$ Anot autorių, kariniam vadų rengimui taikos metu turi būti skiriamas ypatingas dèmesys, ugdant juos ne tik kaip asmenybes, bet ir kaip komandos narius, kurie gali pasiekti teigiamų rezultatų mūšyje tik gebėdami veikti tiek su kitais vadais, tiek su savo koviniu vienetu.

Toliau paliečiamas vado svarbos aspektas, kurio tikètinas tikslas - paaiškinti, kodèl kariai, perskaitę šias knygas, turètų pradèti kitaip vertinti savo vadus. Pirmiausia atkreipiamas dėmesys i priešiškų jejgų sieki pakirsti karių pasitikejjimą savo vadais dar iki karo pradžios, nes tai veikia kaip stipri demotyvacinė priemonè, kartu, net ir nepavykus vadų sukompromituoti, kariai privalo suprasti, jog ir toliau bus dedamos pastangos to siekiant ir neigiamos propagandos dozè gali būti nuolat atnaujinama. Antra, aiškinama, kodèl aukštesnieji vadai nekovoja pirmose pozicijose su eiliniais. Ir nors eilinių karių nepasitenkinimas suprantamas, yra daug logiškų paaiškinimų, kuo rizikuoja vadai, būdami šalia ugnies linijos. Trečia, atsakoma i priekaištus, kodèl vadai, skirtingai nuo eilinių karių, jodinèja raiti, važinėja automobiliais, kai pastarieji žygiuoja, ir iškart mèginama paaiškinti, kad vadovavimas - tai sunkus darbas, o vadas nuolat turi daug rūpesčių, tad kiekviena minutė jam svarbi, jog jis rūpinasi ne tik besikaunančiaisiais, siųsdamas juos iš vienos vietos ị kitą, bet ir sklandžiu užnugario darbu, kad reikalingi dalykai kovotojus pasiektų laiku ${ }^{45}$.

Be vadų darbo svarbos, aptariamos jų kritikavimo priežastys ir padariniai. Siekiama paaiškinti, kad dažnai vadovavimo kritikai, ypač žemesniųjų grandžių kariai, visiškai nesupranta didesnio masto aplink vykstančių dalykų. Tai nereiškia, kad kritikos negali būti, bet ją privaloma pamatuoti, išsiaiškinti vadų pasirinkimų aplinkybes: „Kalbèti turime ramiai, nepereiti ị kraštutinumus, nekaltinti aklai tų, kurių darbo nepažįstame ar kurių darbas turi likti slaptas <...> svetimiesiems mes

\footnotetext{
44 Karinio auklejjimo paskaitos. II knyga. Kaunas, 1940, p. 259.

45 Ten pat, p. 261-263.
} 
neturime išduoti net ir to, ką galvojame apie savo vadovybę, apie karo galimumus." ${ }^{46}$

Galiausiai pateikiamos išvados:

„1) Vadovavimo darbas labai reikšmingas, nes be gero vadovavimo netenka reikšmès mūsų pasirengimas karui.

2) Vadovavimo darbas painus ir sudètingas; reikia vadovavimo darbui gerai pasirengti taikos metu.

3) Visiškai nepagrịsti yra karo metu vadams daromi priekaištai, esą jie sèdi giliai užnugary, naudoja arklius, automobilius, kai eiliniai kareiviai eina pėsti, naudojas asmeninių pasiuntinių patarnavimais ir t. t. Kiekvienas turime mokèti tokius kaltinimus atremti.

4) Neturime pasiduoti nesveikai madai - nekęsti štabų bei tarnybų pareigūnų.

5) Vadų darbą kritikuodami turime būti labai atsargūs, kad nekritikuotume tai, ką nesuprantame arba apie ką neturime pakankamai žinių $<\ldots>$

6) Turime dèti visas pastangas vadų darbui lengvinti. To pasieksime sąžiningai pasirengdami kautynèms, stropiai pildydami mums uždedamas pareigas, o ịtemptų kautynių metu stengdamiesi išlaikyti ramius nervus, nugalèdami baimès jausmą. " ${ }^{77}$

Apibendrinant Karinio auklejimo paskaitu mintis apie vadovavimą ir vadų darbą galima padaryti kelias išvadas, ką stengiamasi kariams paaiškinti. Pirma - kad vadovauti sunku ir kad einant vado pareigas tenka ne tik prsiimti vadovavimo naštą, bet ir būti nuolatiniu taikiniu tiesiogine ir netiesiogine šio žodžio prasme tiek priešui, tiek saviems. Antra, vadas dažnai žino daugiau už pavaldinius, bet ne visada dèl ịvairių priežasčių gali šias žinias jiems perteikti, net jei ir norètų, nes karo metu aplinkybès verčia jị veikti greitai. Bet koks delsimas gali būti lemiamas. Trečia, vado darbas - ne populiarumo varžybos, ir jo tikslas dažniausiai nèra būti mégstamam. Jo tikslas - gerai atlikti vado darbą, bet be pavaldinių paramos jis to niekada nesugebès padaryti. Ir galiausiai ketvirta - vadovauti reikia mokytis, treniruotis, šiam darbui rengtis, nes tai nèra duotybe்.

\footnotetext{
46 Ten pat, p. 264.

47 Ten pat, p. 265-266.
} 


\section{Trečioji grupė: karinė periodika}

Trečioji grupè, skirtingai nuo pirmosios ir antrosios, ypatinga tuo, kad yra paremta karių ir civilių asmeniniais samprotavimais apie karini vadovavimą, vadą, jo kompetencijas ir pan. Taigi galima teigti, kad trečioji grupè yra labai subjektyvių asmeninių pažiūrų rinkinys, kita vertus, tai - XX a. 4-ojo dešimtmečio vadovavimo diskurso atspindys. Toliau pateikta medžiaga apima tuo metu vykusias diskusijas apie karinị vadovavimą, vadus ir su jais susijusius dalykus. Pagrindinès mintys paimtos iš tarpukario periodinių leidinių, tokių kaip Müsų žinynas, Kardas, Karys ir Kariūnas, straipsnių.

1933 m. Pagrindiniai sprendimo elementai. Gen. št. pulk. Grinius ${ }^{48}$. Šis straipsnis yra tarsi logiškas $1932 \mathrm{~m}$. Stambesniu kariuomenès junginiu vadovavimo laikinuju dessniu doktrinų tęsinys, analizuojantis itin aktualią sprendimo prièmimo proceso problematiką. Analizuojant vèliau išleistus ¡̇vairiu kariuomenès pajègų statutus pastebima akcentuojama mintis kad vado gebëjimas priimti sprendimą yra viena svarbiausių sèkmingo veikimo sąlygų. Pažymètina, kad šiame straipsnyje ypatingas dėmesys skiriamas sprendimo priemimo procesui, orientuotam $\mathfrak{i}$ karinius veiksmus, bet su tam tikromis išlygomis gali būti taikomas ir kasdienejje tarnyboje.

„Svarbiausiasis vado vaidmuo kautynèse pasireiškia sprendimu. Konkretus vado sprendimas, savaime suprantama, tinka tik tam tikram ribotam laikotarpiui. <...> Sprendimų kiekio ir jų dažnumo nepaisant, pats sprendimo prièmimo procesas visais atvejais be žymesnių pakeitimų lieka tas pats. <...> Pažvelgę ị daugumos kariuomenių stambesnių junginių vadovavimo nuostatus, matome, kad vado sprendimui pagrindine baze būna:

Aukštesnio vado duodamas uždavinys;

Savo jègos: dalinių kiekis ir kokis, valdinių gabumai ir jų būdas, medžiaginio pobūdžio priemonès;

Padètis priešo atžvilgiu;

Visuma kitų faktorių (vietovès pobūdis, kelių tinklas, oras, laikas ir t. t.) $<\ldots . .>$

Aukštesniojo vado duodamas uždavinys yra pagrindinis sprendimo

48 GRINIUS, K. Pagrindiniai sprendimo elementai. Mūsų žinynas, 1933, Nr. 99, 100. 
elementas $<\ldots>$ Patyrimas ir praktika rodo, kad daug vykdymo klaidų pareina ar nuo pamiršto, ar nuo nepakankamai gerai suprasto uždavinio $<\ldots>$ nagrinejjant atskiro uždavinio veiksnị, reikia nepamiršti, paanalizuoti tiek aukštesnio junginio bendrą uždavinị, tiek ir atskirų kaimynų uždavinius. <...> idealus dalyko sprendimas glūdi tokiame uždavinio formulavime, kur vykdytojas gauna tikslą, o priemones šiam tikslui pasirenka savo nuožiüra. <...> kiekvienu konkrečiu atveju vadas turi nustatyti savo valdiniams iniciatyvos ribas. $<\ldots .>$ tikslus turimų priemoniu apskaičiavimas yra pirmoji sprendimo sąlyga. $<\ldots>>$ priešo padètis įvertinti pasidare visai lengva. Šis įvertinimas - labai svarbus vado sprendimo veiksnys. <...>

Dalinio moralinè verte yra ne kas kita, kaip tik tas atsparumas, kuri dalinys sugeba parodyti sunkiomis valandomis. Ji pareina pirmiausia nuo atskirų kovotojų dvasios vertès. Be individinès dvasios, sudarytoje dalyje kuriasi dar kolektyvinè dvasia. <...> Kol dalies solidarumo jausmas nèra subrendęs, dalinys negali duoti savo maksimumo našumo $<\ldots>$ pirmieji karo susirèmimai turi lemiamos reikšmès visai tolesnei karo eigai ir kad junginiai ịvesti ị pirmąsias kautynes turi būti labai rūpestingai parengti. $<\ldots>$ Geriausias elementas - gabūs vadai ir drąsūs kareiviai, priešo žudomi nyksta. <...> Nèra reikalo sakyti, kad visas vadų patyrimas ir jų pastangos kaip tik šią bendro nuovargio ir pesimizmo valandą turi būti taikomos ir naudojamos iki galo. Priešingu atveju pats karo sèkmingas išsprendimas gali būti nepataisomai sukompromituotas. ${ }^{\text {" }}$

„VII. Vadovybè. Kovotojų masė be vadų - bejegè, lygiai kaip ir vadai be kovotojų. <...> Vado vaidmeniui pasirengti žmogaus gyvenimo ne per daug. Vieno darbo nepakanka. Didesnio masto vadui reikia gilios intuicijos ir ypatingos energijos. Vien tik operacijų komplekso analizas (sprendimui gauti) negali tos intuicijos visiškai pakeisti. <...> Vado vaidmuo pirmiausia - veikti. Vien tik mokèti (žinoti) nepakanka. Bet mokèti (žinoti) - būtinas dalykas. <...> Žmogaus inteligencija turi padaryti tam tikrą šoksmą. Iš to išeina, kad nèra reikalo norèti gauti sprendimą deduktyvaus protavimo metodu. Tik analizą ir sintezị iš eilès kaitaliojant, galima prieiti iki galo. Šios dvilypès operacijos keliu, protas savyje susiras tinkamą sprendimą. <...>

49 GRINIUS, K. Pagrindiniai sprendimo elementai. Mūsų žinynas, 1933, Nr. 99, p. 425436. 
Vadovavimo metodai. Kariuomenès vadovavimas, plačia šio žodžio prasme, yra gana specialus, savotiškas dalykas. <...> Vadas savo valdiniams tiesiog nekomanduoja: jis ịsako žemiau stovintiems vadams, kurie savo ruožtu įsako savo valdiniams. Visi vadai turi jiems skirtą kompetenciją ir tos kompetencijos ribose didesnị ar mažesnị savarankiškumą. Darniam ir sèkmingam darbui pasiekti būtinai reikia valdiniams palikti tam tikros iniciatyvos laisvę. <...> Pats vadas taip pat nèra izoliuotas. Jis dažnai mato savo valdinius, kalba su jais, jiems praneša savo įspūdžius, savo nusistatymus; jis tariasi su jais; kartais, prireikus, jis jiems praneša ir savo sprendimo motyvus. <...> Vadovavimo menas glūdi mokejjime rasti pusiausvyrą tarp to, kas turi būti paties vado įsakoma, ir to, kas turi būti paliekama valdinių iniciatyvai. <...> Nors vadui, iš principo, ir nekenksminga žinoti aplinkybių smulkmenos, tačiau, iš antros pusès, jis neturi būti per daug jomis užverčiamas. Turèdami tatai galvoje, mes ir skyrème sprendimo sąvoką nuo įsakymo sąvokos, t. y. nustatyti paties vado ir jo štabo vadovavimo prerogatyvas. <...> Tik tvirto būdo vadas ir gali vadovauti. Tik šia sąlyga jis galès pateisinti savo vadų, kariuomenès dalių ir šalies pasitikejjimą. ${ }^{\text {"50 }}$

Skaitant ši straipsnị stebina jo gilumas ir stiprus mokslinis pagrindas, kuriam atsirasti padejo Paryžiaus karo akademijos plk. Lemoine kurso medžiaga. Kertinis sprendimo priemimo proceso naratyvas yra įsakymo davimo ir sprendimo priẻmimo priešprieša. Tai nereiškia, kad šie du dalykai yra atsieti. Tai reiškia, kad bet kuris įsakymas sprendimo priemimo proceso metu turi būti išmąstytas, tada atlikta aplinkybių ir duomenų analizė leistų žinias apibendrinti ir sukurti pagrindą ịsakymui atsirasti. Neapmąstytas, paskubomis parengtas ịsakymas gali negarantuoti norimo rezultato, jei apie toki išvis buvo galvota. Sprendimo priėmimo procesas nèra toks prievartinis kaip „tiesiog“ ísakymas, nes ypač sudètingose situacijose karo metu, patiriant gyvosios jėgos ir materialinių nuostolių, kai mažeja dalinio moralinis atsparumas, duodant „tiesiog“ issakymus, galima per trumpą laiką prarasti pavaldinių pasitikejjimą vadais. Sprendimo prièmimo procesas leidžia iš dalies išvengti kvailų netekčių, nes padeda numatyti galimus padarinius ir pasirinkti būdus jiems sumažinti. Galiausiai tarp „tiesiog“ issakymo ir sprendimo priemimo yra ir dar vienas esminis skirtumas, suvedamas $\mathfrak{i}$ tam tikros veikimo laisvès ir inici-

50 GRINIUS, K. Pagrindiniai sprendimo elementai. Mūsų žinynas, 1933, Nr. 100, p. 1-12. 
atyvos egzistavimo naratyvą. „Tiesiog“ i̇sakyme viskas būna ịrėminta ir iki smulkmenų aprašyta, o sprendimo prièmimo situacijoje aukštesnysis vadas paprastai turètų turèti tik tiek žinių, kiek jų reikia pavaldžių vadų veiksmams dekonfliktuoti, ir galètų palikti iniciatyvą veikti patiems. Dèl šios priežasties straipsnyje ir paminèta, jog visi vadai turi būti susipažinę su kaimyninių padalinių vadų užduotimis, kad, veikdami nesuderintai, nesugadintų to, kas suplanuota. Kartu keliami aukšti reikalavimai vadų inteligencijai ir būdo tvirtumui, nes be šių savybių sudètingų procesų neimanoma efektyviai igyvendinti.

$1934 \mathrm{~m}$. Keli Lietuvos karininko tipo bruožai. Jonas Noreika ${ }^{51}$. Šis straipsnis buvo $1933 \mathrm{~m}$. Kardo žurnalo 2-ame numeryje išspausdinto straipsnio „Mūsų karininko tipas“, kuriuo siekta pradèti diskusiją, koks turètų būti Lietuvos karininkas, tęsinys. Jonas Noreika rašo apie trejopą karininko padètị: šeimoje, tarnyboje ir visuomenèje. Anot jo, tuo remiantis ir reiketų karininką vertinti.

Po šio straipsnio pasirodè keletas kitų autorių straipsnių, kuriuose mėginta atliepti J. Noreikos mintis bei argumentuotai diskutuoti dèl tam tikrų aspektų: „Kiekvienas žmogus veržiasi ten, kur jis gali. Taip ir būrio vadas. Jaunas, energingas, didele lietuvio potencine jèga ieško apčiuopiamo darbo. Nors nuotaika kiek pagenda, pastebint senųjų konservatyvizmą, tačiau jų duodami tiktai bendri nurodymai nekliudo stengtis perprasti kareivių sielas $<\ldots$. ir einama kaip tik teisinga kryptimi - ne pabaudų skyrimu, o taktingumu ir mokejimu taip dèstyti programinius dalykus, kad kareiviai visada lauktų jo pasirodymo. $<\ldots>$ taip individualiai bepraktikuodamas, būrio vadas igyja ir savotišką kareivių psichologijos supratimą <...> todèl kai kas nors iš vyresniųjų pradeda kitokius samprotavimus dèstyti dèl kareivių mokymo metodų, būrio vadas visa tai laiko nepatikrinta teorija, arba „pervirškinęs“ pritaiko savo individualinei metodikai<...> Iš to, ką nusakème šiame skyrelyje apie karininką tarnyboje, kas ypač ryšku pèstininkų dalyse, suglaudę gausime tokių išvadų:

a) „Ambicingas, jautrus senų kuopos vadų charakteris reiškiasi psichologiškai stipria ịtaka kareiviams ir atsiskiria nuo jaunųjų karininkų ${ }^{52 “}$.

b) „Būrių vadai, ieškodami vidujinio pasitenkinimo atsakingose pareigose, visą energiją deda ị kareivių mokymą, net tarpusavy lenktyniuo-

51 NOREIKA, J. Keli Lietuvos karininko tipo bruožai. Kardas, 1934, Nr. 6, 7, 8.

52 NOREIKA, J. Keli Lietuvos karininko tipo bruožai. Kardas, 1934, Nr. 7, p. 130-131. 
dami <...>

Kiekvienas karininkas, dirbdamas tiesiogini jam pavestą darbą, dirba jị ne sau, o kitiems. Dirba visuomenei, tautai <...> Būtų per didelis nukrypimas nuo temos kalbėti apie karininko išsilavinimo reikšmę visuomeniniame darbe. Mums daugiau rūpi, kaip jis reiškiasi, koks jis yra. Iš ko galima spręsti apie žmogaus išsilavinimą? Man rodosi, iš jo pastangų save lavinti, iš to kiek laiko jis atideda intelektualiniam darbui ir iš atsiektų to darbo rezultatų <...> Karininkams net patariama, o iš stojančių i akademijos kursus netiesioginiu būdu reikalaujama turèti rimtas politinis išmanymas <...> Glaudus, nuoširdus prisirišimas prie kareivių, pastangos patraukti juos ị save, reiškiasi ypač Lietuvos istorijos pamokose. Tuo būdu auga sveikas patriotizmas. <...> Viešose vietose karininkas pasirodo visada tvarkingai apsirengęs, užgautas energingai reaguoja, moka reprezentuoti. <...> Šalies kultūriniams reikalams karininkas gana jautrus. $<\ldots>$ Karininku labai pasitikima ir, žinoma, ne be pagrindo. Duotajj žodi išlaiko, terminuotajji pasižadejimą stropiai realizuoja. <...> Karininkas drausmingas. " 53

Apžvelgiant pagrindines J. Noreikos mintis pirmiausia reikètų pasakyti, kad jo straipsnis, nors ir didelès apimties, atrodo gana chaotiškas, be aiškios sistemos ar mokslinio pagrindo, nepaisant autoriaus pastangų apibrèžti karininko aplinką (šeima, tarnyba, visuomenė) ir kai ką susisteminti. Analizuojant straipsnị matyti, kad mètomasi tarp formalaus ir neformalaus karininko elgesio ypatybių, jam taikomų reikalavimų, ji supančios ir veikiančios aplinkos bei kitų sunkiai tarpusavyje susijusių veiksnių ir beveik nekalbama apie pati vadovavimą:

1. Pirmasis akcentas yra karininko asmeninio pavyzdžio formavimas. Jis apibrèžiamas, kaip asmuo, kuris ne tik dèl savo asmeninių savybių, išsilavinimo ir pan., bet ir dèl einamų pareigų privalo būti tas, kuris tiesiogiai rūpinasi pavaldžiais kariais, nes dirba ne sau, o šaliai, visuomenei. Kertine bendravimo su pavaldiniais ašis - individualus dèmesys kiekvienam kariui ir jo reikalams, nes ne visi mokymo, auklejjimo metodai vienodai tinka visiems kariams. Be to, jo darbo rezultatai ir efektyvumas priklauso nuo asmeninio pavyzdžio, jam, kaip karininkui, taikomų standartų, kurių besilaikančiam aplinkiniai suteikia pasitikejjimo mandatą.

2. Antrasis akcentas, kurị stengiamasi išskirti, yra karininko inte-

53 NOREIKA, J. Keli Lietuvos karininko tipo bruožai. Kardas, 1934, Nr. 8, p. 152-155. 
lektualumas. Intelektualumas pasireiškia ịvairiomis formomis, pradedant išsilavinimu ir baigiant bendru išprusimu, ịskaitant ir kasdieninių valstybės reikalų suvokimą. Anot J. Noreikos, karininko intelektualumas leidžia efektyviai rengti pavaldžius karius, ugdyti jų patriotizmą ir skatinti siekti daugiau. Intelektualumas siejasi su asmeniniu pavyzdžiu. Tik išprusęs, nuolat besilavinantis ir adekvačiai situaciją suvokiantis vadas yra pajègus visapusiškai parengti karius ne tik kovos, bet ir kasdienès tarnybos situacijoms. Intelektualumas padeda sukurti pasitikèjimo vadu atmosferą, o asmeninis pavyzdys - ją išlaikyti.

1934 m. Lietuvos karininko tipas. Plk. Julius Čaplikas ${ }^{54}$. Šis straipsnis buvo reakcija ị minètą J. Noreikos straipsnị ir iš dalies jo kritika, kad pateiktas karininko vaizdas neišsamus. Pulkininkas mėgina kitaip susisteminti pagrindines nuostatas ir aptarti karininko ịvaizdžio klausimą. Jis pabrěžia devynis aspektus: tautiškumą, bendrąji ir karinį išsilavinimą, būdą, tarnybą ir jos pamėgimą, drausmę, karjerą, santykius su valdiniais, privatų gyvenimą ir santykius su visuomene bei šeima.

Iš minètų temų čia bus analizuojamos tik tos, kurios susijusios su karinio vadovavimo samprata.

„Bendras išsilavinimas, stojant $\mathfrak{i}$ karo mokyklą, laikoma ganètinu, baigus gimnaziją. Be šio bendrojo išsilavinimo, karininkas turi suprasti masès (kareivių) psichologiją ir mokèti igyti jų pasitikẻjimą taikos metu, o ypač kare. Be to, karininkas turi gerai suprasti šalies ekonominę būseną, kad galètų objektyviai ịvertinti šalies pajègumą išteklių atžvilgiu. $<\ldots>$ Naudingas karininkas bus tas, kuris pirmiausia rūpinsis kariškai lavintis, o bendrajj̨ lavinimą gilins ir papildys žinias, skaitydamas specialius vekalus ir lankydamas viešas naudingas jam paskaitas. <...> Lietuvos karininko būdas turètų būti stiprus, mažiausiai vidutinis, o silpno būdo karininkas nepageidaujamas $<\ldots>$ Karininkas turi su pamėgimu mokslinti ir auklèti gautąji naujoką, kad šis, baigęs tarnybą ir grįžz̨s namo, įneštų i kaimą sveiką tautišką dvasią “55. „Karininkas taip pat duoda priesaiką ir pasižada besąlygiškai klausyti savo viršininkų ịsakymų ir paliepimų, išskiriant aiškiai nusikalstamus. Drausmingas karininkas visuomet žinos ribas, jis bus drausmės pavyzdžiu kitiems karininkams ir kareiviams. $<\ldots>$ Idealas būtų, kad privatiniame gyvenime karininkas būtų valdinių

${ }^{54}$ ČAPLIKAS, J. Lietuvos karininko tipas. Kardas, 1934, Nr. 9, 10.

55 ČAPLIKAS, J. Lietuvos karininko tipas. Kardas, 1934, Nr. 9, p. 170-171. 
nuoširdžiai gerbiamas, mylimas, bet tatai pasiekti sunku <...> Tiek tarnyboje, tiek ir privatiniame gyvenime reik vengti asmeniškų sąskaitų suvedimo, iš to būna daug žalos viršininkų ir valdinių santykiams. <...> Su civiliais mandagus, nenori nuo jų išsiskirti, nori turèti glaudžius, gerus santykius, jis turi aiškią savo nuomonę ypač politinių partijų atžvilgiu, visi pajutę, kad jų draugystès narys - karininkas aukščiau politinių jų ìsitikinimų, vien valstybiškai nusistatęs $<\ldots>$ jo draugystėj nariai jaučia, kad prieš save turi išsilavinusị asmenị su aiškiu nusistatymu. <...> Iš viso, kas pasakyta, išeitų, kad Lietuvos karininko tipas būtų toks: tautiškai nusistatęs, mylịs gimtąji kraštą, karo ir bendrųjų žinių turi daug ir jas gilina, stipraus būdo, drąsus, drausmingas, laipsnị nori gauti vien sąžiningu darbu, santykiuose su valdiniais tarnyboje griežtas, teisingas, privatiniame gyvenime draugas. Savo gyvenime tvarkingas, visuomene ji brangina, kaip didelès vertès asmeni. ${ }^{\text {" }}{ }^{6}$

Kaip mokslinis, plk. J. Čapliko straipsnis, kaip ir J. Noreikos, yra gana paviršutiniškas, labiau atspindintis asmeninę nuomonę, kurią bandoma pagrịsti dalykais iš karinès patirties, be jokios tvirtos sistemos ir nesiriament doktrininiais kariuomenès dokumentais. Be to, toks straipsnis labiau skirtas karininko asmenybei, o ne karinio vadovavimo ypatumams aprašyti. Apibendrinant galima išskirti keletą aspektų:

1. Išsilavinimas. Jis suprantamas labai panašiai kaip ir kituose minètuose šaltiniuose, tik šiame straipsnyje pabrèžiama dar viena detalè, kuri kitur nebuvo itin akcentuojama, - politinis išprusimas. Jis leidžia esamą valstybės situaciją suprasti plačiau bei ją išaiškinti pavaldiniams, nes tai iš dalies siejasi ir su jų valia kautis už savo šalị ir lemia pastarųjų patriotinị nusiteikimą. Be to, anot J. Čapliko, politikos žinios gerina karininko ịvaizdị visuomenėje, ypač bendraujant su civiliais, nes geras išsilavinimas pabrèžia karininko, kaip visuomenès elito, statusą. Galiausiai pabrèžiama, kad karininkas turi nuolat lavintis ir šviestis.

2. Būdo savybės. Tarnyboje - stipraus būdo, drausmingas, drąsus, sąžiningas, griežtas, teisingas, tvarkingas, besilaikantis taisyklių ir ịsakymų, bet neformalioje aplinkoje - draugiškas ir rūpestingas.

$1934 \mathrm{~m}$. Taikos meto valstybés ginkluotu jëgu vadovybés organizacijos

56 ČAPLIKAS, J. Lietuvos karininko tipas. Kardas, 1934, Nr. 10, p. 186-188. 
problema. Plk. ltn. Ramanauskas ${ }^{57}$. Jis, skirtingai nei du minèti $1934 \mathrm{~m}$. straipsnių autoriai, analizuoja strateginio vadovavimo lygmens iššūkius, remdamasis gausiais kitų valstybių pavyzdžiais. Šie dalykai aktualūs, nes yra susiję su tuo metu nusistovejjusia doktrinine Lietuvos kariuomenès ir politinio lygmens ginkluotųjų pajègų valdymo sistema. Esminiu iššūkiu laikomas vadovavimo ir darbų pasiskirtymo tarp krašto apsaugos ministro ir kariuomenės vado dualumas, kuris pasireiškia tam tikrų pareigu dubliavimu, kai būtų galima iš esmès jas atskirti ir palikti krašto apsaugos ministro kompetencijai tik atstovavimo kariuomenei pareigą civiliniu strateginiu lygiu. Visi kiti klausimai, t. y. kariuomenès rengimas karui, logistika, ịsigijimai ir kasdieniai administraciniai reikalai, liktų kariuomenès vadui spręsti. Tai leistų jam efektyviau tobulinti kariuomenę visomis prasmėmis: „Krašto apsaugos ministeriui pavedama, paprastai, daugiau teisinè valdymo pusé, kariuomenès aprūpinimas ir reikiamų jai išlaikyti lèš gavimas ir tiekimas, o numatomas kariuomenès vadas daromas, paprastai, atsakingas už kariuomenès rengimą karui. Bet neaprūpintą kaip reikiant kariuomenę, nors ji geriausiai būtų apmokyta, negalima laikyti tinkamai parengta karui. Tinkamas kariuomenès medžiaginis aprūpinimas turi ne mažesnès reikšmès negu jos mokymas. Todèl visai natūralu, kad tas, kas yra atsakingas už kariuomenès rengimą, turi žiūrèti ne tik jos mokymo, bet ir aprūpinimo <...> Jei stambiųjų kariuomenès junginių vadų rankose racionalu ir reikalinga, kad būtų sukoncentruotas kariuomenès mokymas ir aprūpinimas <...> Todèl ir kariuomenės aprūpinimą būtų tikslu pavesti kompetentingam karo dalykų žinovui, numatomam kariuomenès vadui, nežiūrint, kurị pavadinimą jis turètų taikos metu. "58

Autorius straipsnyje vengia minèti Lietuvą ir jos karinę sistemą apskritai, lyg siektų apsidrausti, kad nebūtų palaikytas sistemos ardytoju, o pabaigoje dar pabrèžia, kad nenorèjo teikti karinei vadovybei kokių nors konkrečių pasiūlymų, tiesiog iškèlè egzistuojančias problemas. Nepaisant to, straipsnis gana aktualus ta prasme, kad kariuomenės dalinių vadams, tikètina, nebuvo svetimos diskusijos, kaip galima būtų pagerinti vadovavimo sistemą, kad veikla taptų labiau organizuota ir efektyvesnè.

1939 m. Vado asmenybès reikšmè. Gen. št. plk. ltn. Antanas Simanas

57 RAMANAUSKAS, ?. Taikos meto valstybès ginkluotų jègų vadovybès organizacijos problema. Mūsų žinynas, 1934, Nr. 114, p. 193-206.

58 Ten pat, p. 205-206. 
Réklaitis $^{59}$. Šis straipsnis apie vadus - tiek karininkus, tiek puskarininkius. Jame nèra aiškios takoskyros tarp vado ir vadovavimo. Dėmesys sutelktas ir akcentuojama, kad tinkamas auklejimas ir asmeninio tobulejimo siekis yra tai, kas sukuria stiprias asmenybes, kurių dèka karinejje srityje įmanomi aukšti rezultatai. Autoriaus nuomone, jo paminèti vadai nebuvo genijai iš prigimties ir neturejo išskirtinių gabumų. Tai, ko jie pasiekè, yra dèl „nuolatinio ir planingo darbo, nuolatinio tobulinimosi, stiprinant savo asmenybę ir ugdant teigiamus, kaipo žmogaus privalumus"60.

Toliau pateikiamos kertinès S. Rèklaičio straipsnio citatos, geriausiai atspindinčios jo požiūrị i vado svarbą: „Vadų svarbiausias uždavinys ir atsakomingiausia pareiga yra parengti savo kovotojus-valdinius (kareivius ir karininkus) morališkai, išugdyti juose tokias dvasines savybes, kurių, kaip žinome, negalime išugdyti nei įsakymais, nei pabaudomis, nei dresūra $<\ldots>$ susidominimo, pamėgimo ir atsidavimo vado pašaukimui, atseit pareigoms, negalima žmoguje nei išdirbti, nei drausmès keliu išugdyti <...> šių privalumų vadas igauna tik būdamas savo vyresniųjų šia kryptimi auklèjamas <...> Savo valdinių auklejjimui teigiamos įtakos turès tik tie vadai, kurie ị vado pašaukimą (pareigas) žiūrès plačiau ir giliau, kurie stengsis ne tik kalbèti, bet ir veikti, kurie norès ir sugebès i savo darbą įdèti visą savo sielą <...> Kad gautume kiek pilnesnị vado asmenybès vaizdą, panagrinèkime jo bent kai kuriuos privalumus bei būdingesnius bruožus:

1. Atsakomybės jausmas. Kiekvienas vadas turi turèti gerai išvystytą atsakomybės jausmą, nes be jo neįmanomas sẻkmingas vadovavimas $<$...> Atsakau už karinị savo dalinio parengimą ir jo auklejjimą, atsakau už savo valdinių likimą, o taip pat atsakau už savo veiksmus - taip privalo kiekvienas vadas samprotauti, jausti ir veikti <...>

2. Vadas ir sunkiausiu momentu turi būti ramus (šalto būdo). Jis visais atvejais turi savo valdiniams būti gyvu pavyzdžiu. <...> Vado ramumas (šaltumas) yra vienas svarbiausių jo asmenybės savybių. <...> Ramumas - šaltumas tai didelè vado savybè teikianti jam neišsemiamo kapitalo jo sunkiose ir atsakingose pareigose. <...>

3. Vadas turi mokèti baimès jausmą suvaldyti. <...> Vadas, sugebąs

59 RĖKLAITIS, A. S. Vado asmenybės reikšmè. Mūsų žinynas, 1938, Nr. 11-12, p. 659670.

60 Ten pat, p. 659. 
taip susivaldyti ir sunkiausiose aplinkybėse, labiausiai priartėja prie karžygiškumo. $<\ldots>>$

4. Taktas. <...> Vado taktas yra jo sugebejimas vykdyti savo kilnų pašaukimą (pareigas) neužgaunant kitų jausmų, ịsitikinimų, bet savo kilnia asmenybe imponuoti kitiems ir juos gerai nuteikti. Vado taktas labai tampriai rišasi su jo mandagumu ir korektiškumu. <...>

5. Pasitikejjimas. Iš karo patyrimų žinome, kad daliniai kautynèse pareikšdavo stebuklingos drąsos - narsumo tik todèl, kad savo vadams tikejjo, kad juos mylejo ir gerbè $<\ldots>$ jo ịsakymų tikslumui niekas neabejodavo $<\ldots>>$

6. Vado suartejimas su valdiniais - tai labai svarbi sąlyga sèkmingam vadovavimui ir vado autoritetingumui $<\ldots>$ Dabar kiekvienas vadas issitikino, kad autoritetui palaikyti nepakanka grynai drausmès ir kariškų statutų žinojimo. Jis dabar suprato, kad norint turèti autoritetą <...> vadas turi būti pranašesnis už savo valdinius tiek dvasiniais, tiek fiziniais privalumais $<\ldots>$ vadas turi būti glaudžiame kontakte su savo valdiniais (su mase), jis turi su jais bendrauti." ${ }^{61}$

Apibendrinant esmines A. S. Rèklaičio mintis pabrěžtina, kad karinis vadovavimas kaip terminas nèra išskiriamas, t. y. vadovavimas, kaip reikètų suprasti, yra tai, ką daro vadas, neteikiant šiam reiškiniui gilesnès mokslinès prasmès. Ši nuostata labai primena anksčiau analizuotus J. Noreikos ir J. Čapliko straipsnius, kuriems galima prikišti sistemiškumo ir asmeninès nuomonès trūkumą ir kurie, tikètina, buvo parengti remiantis asmenine darbo su kariais patirtimi, stebint, kas veikia, o kas ne. Nepaisant to, A. S. Rèklaičio straipsnis vis dèlto yra gerokai analitiškai gilesnis, nes, skirtingai nuo J. Noreikos ir J. Čapliko publikacijų, autorius labai aiškiai susitelkęs ị šešis punktus, kurie, anot jo, yra efektyvaus vado sampratos pagrindas. Iš pastarųų galima kildinti ir kitus visuotinai priimtus teiginius apie vadovavimą, kad jei jis nėra visiškai teisingas, vargu ar verta tikètis iš vado pozityvių rezultatų, nepaisant jo karinių kompetencijų - taktinių gebejimų, intelektualumo ir išsilavinimo.

1939 m. žurnalas „Kariūnas“, Nr. 1, asp. M. Ruseckas, asp. B. Rama-

${ }^{61}$ RĖKLAITIS, A. S. Vado asmenybès reikšmè. Mūsų žinynas, 1938, Nr. 11-12, p. 661668. 
nauskas $^{62}$, Nr. 2, ltn. V. Stanevičius ${ }^{63}, N r .3$, A. Pamataitis ${ }^{64}$. Idomu, kad prieš netenkant nepriklausomybės pagausejo ịvairių straipsnių, susijusių su vadų vaidmeniu, vadovavimu, ne tik kariuomenès periodiniuose leidiniuose, bet ir žurnale Kariūnas, kurị leido Pirmojo Lietuvos Prezidento karo mokyklos kariūnai ir aspirantai. Vien 1939 m. žurnale buvo publikuoti 4 straipsniai, kurių autoriai labai skirtingai pabandè pažvelgti i vado savybes ir vadovavimą.

M. Ruseckas, A. Pamataitis ir B. Ramanauskas savo straipsniuose mégino išrinkti svarbiausias, autorių nuomone, karininko savybes ir kompetencijas, kurių reikia, kad jị būtų galima vadinti geru karininku. Vertinant per tuo metu egzistavusių doktrinų prizmę, nepanašu, kad nors vienas iš jų ieškojo sistemiško požiūrio ị vadovavimą, ir matyti, kad labiau pateikè savo asmeninę nuomonę, nei doktrininį vertinimą. Kita vertus, gana akivaizdu, kad visi šie autoriai pateikẻ nemažai panašių minčių, todèl darytina prielada, jog jie neišvengiamai turèjo būti susipažinę ar remtis tam tikra su vadovavimu susijusia literatūra ir tuo metu vyravusia Lietuvos kariuomenès karinio vadovavimo samprata. Šie straipsniai labiau ịdomūs tuo, kad iki tol Karo mokyklos kariūnai labai mažai rašè vadovavimo klausimais, bet kodèl jų taip staigiai pagausèjo, nepavyko išsiaiškinti. Nepaisant to, šie straipsniai neblogai atspindi bendrą Lietuvos kariuomenès tendenciją vis daugiau dèmesio skirti vadovavimo klausimams, kurie, Europoje tvyrant karo nuotaikoms, ko gero, buvo tikrai aktualūs.

Iš šių keturių publikacijų tik A. Stanevičiaus straipsnyje mėginama i vadovavimo problematiką pažvelgti giliau, t. y. ne pateikti tam tikrus terminus ir trumpus jų apibūdinimus, kaip kituose minètų kariūnų straipsniuose, bet analizuoti vieną konkrečią problemą - karinị auklejjimą. Prisimenant, kad aiškios takoskyros tarp vado, pedagogo ir auklètojo sampratų nebuvo, $\mathfrak{i}$ auklejjimo temą šiame straipsnyje gilinamasi kaip $\mathfrak{i}$ vieną vadovavimo proceso dalių. Autoriaus nuomone, karinis rengimas yra tik dalis to, kuo užsiima vadai. Dvasinis auklejimas yra tai, kam vadas turi skirti kur kas daugiau dèmesio ir jègų, todèl negali pamiršti, kad

62 RUSECKAS, M. Lietuvos karininko tipas. Kariūnas, 1939, Nr. 1, p. 26-31, 40.

63 STANEVIČIUS, V, M. Pasiruošimas auklètojo darbui. Kariūnas, 1939, Nr. 2, p. 26-31, 40.

64 PAMATAITIS. Lietuvos karininko tipas. Kariūnas, 1939, Nr. 3-4, p. 188-193. 
atskirų karinio rengimo dalių tikslai ir dvasinis kario auklejjimas turi sudaryti darnią visumą. Tik tokiu atveju galima tikètis sèkmès. Tokia veikla ịpareigoja karininką pačiam būti pozityviu pavyzdžiu savo kariams ir nuolat tobulintis.

\section{IŠVADOS}

XX a. 4-ojo dešimtmečio karinio vadovavimo samprata yra tam tikras iššǔkis pirmiausia dèl to, kad iki pat šio laikotarpio pabaigos nebuvo iki galo doktriniškai apibrěžta. Antra, kaip galima pastebèti vertinant trijų grupių medžiagą, sukurti konkretesnị apibrèžimą įmanoma tik sujungiant visų grupių panašumus, nes skirtumų yra nemažai. Ir trečia, samprotaujant reikia laikytis pagrindinès pozicijos, kad vadas, vadovavimas, karinis mokymas ir auklëjimas yra sudedamoji vieno proceso dalis:

1. Lietuvos tarpukario kariuomeneje, hierarchinès vadovavimo piramidès struktūros organizacijoje, buvo aiškiai nustatyti vadovavimo lygmenys ir atsakomybès. Kariuomenei strateginiu lygmeniu tiesiogiai vadovavo kariuomenès vadas, pavaldus krašto apsaugos ministrui, o jam buvo pavaldūs kiti vadai. Vadovavimo modelis apèmè keturis esminius dalykus: personalą, aprūpinimą, informaciją ir operacijas. Šių keturių dalių tarpusavio efektyvus veikimas turẻjo užtikrinti ir visos kariuomenès veiklos efektyvumą. Daliniams ir padaliniams vadovavo paskirti vadai, kuriems siekta taikyti aukštus profesionalumo ir asmeninių savybių standartus. Vadas ir vadovavimas traktuoti kaip dvi neatsiejamos vieno elemento sudètinès dalys.

2. Kiekvienas vadas veikè paisydamas aiškios vadovavimo ir valdymo hierarchijos ir pagal savo kompetenciją prisiimdavo atsakomybę, kurios dali turejo perduoti ir savo pavaldiniams. Bazinis principas - centralizuotas sprendimu priemimas ir decentralizuotas vykdymas, remiantis aukštesniojo vado ketinimu, kai žemesniajam vadui paliekama veikimo iniciatyva ir laisvė priimti sprendimus, neperžengiant nustatytų ribų. İsakymai turèjo būti greiti, aiškūs ir konkretūs, t. y. siekiama, kad bet kuris karys, kuriam duotas ịsakymas, suprastų, ko iš jo tikimasi, ir kad netekę tiesioginio vado mūšyje žemesniụjų grandžių vadai galètų imtis iniciatyvos ir tęsti tai, kas pradèta. 
3. Vadas turejo būti pavyzdys savo kariams visomis prasmèmis - tiek kaip savo srities profesionalas, tiek kaip komandos formuotojas, tiek kaip asmenybè. Profesionalumas pasireiške tuo, kad vadas turejo nuolat tobulintis, mokytis, užsiimti intelektualine saviugda bei kelti sau aukštus moralinius standartus tiek tarnyboje, tiek civiliniame gyvenime, t. y. vadovautis karininko etika. Kaip komandos formuotojas, vadas savo asmeniniu pavyzdžiu veikè karius teigiamai motyvuodamas, jis turejo daug investuoti ị visapusị jų karinị rengimą ir auklejjimą, rūpintis kasdieniais poreikiais ir komandos dvasios palaikymu, kad karinis vienetas būtų efektyvus kovinis junginys.

4. Vado žmogiškųjų savybių rinkinyje turèjo dominuoti tokios vertybès kaip iniciatyvumas, atsakomybè, teisingumas ir patriotiškumas. Iniciatyvumas reiškia, kad vadas nelaukia, kol jam kas nors paaiškins, ką daryti, stebi ir vertina situaciją, o pamatęs galimybę, ja pasinaudoja, kad atliktų tai, kas jam pavesta. Atsakomybė suvokiama kaip drąsa imtis iniciatyvos įvertinus galimus padarinius, o suklydus - pasirengimas pripažinti savo kaltę ir priimti už tai gresiančią nuobaudą taip pat ir tada, kai atsakomybę tenka prisiimti už savo pavaldinių veiklą. Teisingumas apima visapusišką ir nuodugnų ịvertinimą, kuriuo remiantis skatinama, skiriami apdovanojimai ar nuobaudos, pagal nuopelnus, nepaisant privilegijų, draugystės ar neapykantos, kai suvokiama, jog visi yra skirtingi, todèl turètų būti ir vertinami skirtingai. Patriotiškumas - tai tèvynès meilè, noras puoselèti lietuviškas vertybes ir propaguoti jas kasdienybeje, atstovauti joms ir būti pasirengus už tai paaukoti savo ir savo karių gyvybes. 


\section{ŠALTINIŲ IR LITERATŪROS SĄRAŠAS}

\section{Archyviniai dokumentai}

II pėstininkų divizijos štabo I skyriaus byla Nr. 2. 1938 m. Karininkų mokymas. LCVA, f. 510, ap. 1, b. 339, 1. 34.

II pèstininkų divizijos štabo I skyriaus byla Nr. 2. 1939 m. Karininkų mokymas. LCVA, f. 510, ap. 1, b. 390, 1. 112, 205, 223.

Karo aviacijos mokykla. Puskarininkių klasės mokymo planas. 193740 m. LCVA, f. 1451, ap. 5, b. 38, 1. 29.

Krašto apsaugos ministerija. Kariūnai-aspirantai. 1930 m. Mokymo byla. $L C V A$, f. 1451 , ap. 2 , b. $24,1.1$.

Vytauto Didžiojo karininkų kursai. Pėstininkų batalionų vadų keturių savaičių kursų mokymo planas. 1938 m. LCVA, f. 1481, ap. 1, b. 153, 1. 6.

Vytauto Didžiojo karo mokykla. Generalinio štabo skyriaus mokymo planas. 1939 m. LCVA, f. 1481, ap. 1, b. 238, 1. 3, 12, 77.

Vytauto Didžiojo karo mokykla. Generalinio štabo kursai. 1935 m. LCVA, f. 1481, ap. 1, b. 84, 1. 13.

\section{Kiti šaltiniai}

ABARAVIČIUS, PLK. LTN. Karo pedagogika (konspektas). II pataisyta laida. Kaunas, 1939, p. 1-20 [žr. 2018-06-04 ir 2019-03-04]. Prieiga per internetą: http://www.epaveldas.lt/object/recordDescription/KVB/ C130000451100

ČAPLIKAS, A. Lietuvos karininko tipas. Kardas, Nr. 10. Kaunas, 1934, p. 171-172, 186-188.

GERULAITIS, Z., generolas leit. Karo istorijos ivadas. Kaunas, 1932, p. 6-9 [žr. 2019-01-13]. Prieiga per internetą: http://www.epaveldas.lt/ object/recordDescription/KVB/C130000482193

GRINIUS, ?. Pagrindiniai sprendimo elementai. Mūsų žinynas, 1933, Nr. 99, p. 425-436.

GRINIUS, ?. Pagrindiniai sprendimo elementai. Mūsų žinynas, 1933, Nr. 100, p. 1-12.

JOKUBAUSKAS, V. „Mažuјų kariuomeniu““ galia ir paramilitarizmas. Tarpukario Lietuvos atvejis. Klaipèda, 2014, p. 172-173, 437, 519. 
Krašto apsaugos ministerija. Artilerijos statutas. A-51. Kaunas, 1937, p. 1-3, 27-31.

Krašto apsaugos ministerija. Karinio auklëjimo paskaitos. I knyga. Kaunas, 1940, p. 3.

Krašto apsaugos ministerija. Karinio auklejimo paskaitos. II knyga. Kaunas, 1940, p. 258-267.

Krašto apsaugos ministerija. Péstininkų statutas. P-51. Kaunas, 1939, p. 1, 78-81.

KELLER, J. Military Leadership and Leaders. ENDC Proceeding, volume 19, 2014, p. 26-27 [žr. 2018-09-02]. Prieiga per internetą: https:// www.ksk.edu.ee/wp-content/uploads/2014/12/KVUOA_Toimetised_19_03_keller.pdf

Lietuvos kariuomenès Generalinio štabo kursų leidinys. Stambesniu kariuomenés junginiu vadovavimo dessniai. Kaunas, 1932 [žr. 2018-06-04]. Prieiga per internetą: http://www.epaveldas.lt/object/recordDescription/ KVB/C130000486053

Lietuvos kariuomenès Mokymo ir doktrinų valdyba. Vadovavimas. $L K$ vadovavimo doktrina $D$-LK-06. Vilnius, 2018, p. 2-15, 4-2.

MCGINN, D. What Companies Can Learn from Military Teams. Harvard Business Review [žr. 2019-01-29]. Prieiga per internetą: https://hbr. org/2015/08/what-companies-can-learn-from-military-teams

NOREIKA, J. Keli Lietuvos karininko tipo bruožai, Kardas, Nr. 6, 7, 8, Kaunas, 1934, p. 130-131, 152-155.

PAMATAITIS. Lietuvos karininko tipas, Kariūnas, 1939, Nr. 3-4, p. 188-193 [žr. 201903 15]. Prieiga per internetą: https://www.epaveldas. lt/object/recordDescription/LNB/LNB014637CA

RAMANAUSKAS, ?. Taikos meto valstybės ginkluotų jėgų vadovybès organizacijos problema. Mūsų žinynas, 1934, Nr. 114, p. 193-206.

RĖKLAITIS, A. Vado asmenybès reikšmè. Mūsų žinynas, 1938, Nr. 11-12, p. 659-670.

RUSECKAS, M. Lietuvos karininko tipas. Kariūnas, 1939, Nr. 1, p. 26-31 [žr. 2019-03-15]. Prieiga per internetą: https://www.epaveldas. lt/object/recordDescription/LNB/LNB014637CA

STANEVIČIUS, V, M. Pasiruošimas auklètojo darbui. Kariūnas, 1939, Nr. 2, p. 26-31, 40 [žr. 2019-03-15]. Prieiga per internetą: https://www. epaveldas.lt/object/recordDescription/LNB/LNB014637CA

Vyriausiojo štabo Spaudos ir švietimo skyriaus leidinys. Kario kalen- 
dorius 1931 metams (365 dienos). Kaunas, 1930, p. 108-111.

Vyriausiojo štabo Spaudos ir švietimo skyriaus leidinys. Kario kalendorius 1937 metams (365 dienos). Kaunas, 1936, p. 6 [žr. 2019-01-31]. Prieiga per internetą: https://www.limis.lt/paieska/perziura/-/exhibit/ mediaObjectPreview/190000010153473/190000010341943?_exhibit Previewportlet_WAR_limiskportlet_backUrl=\%2Fpaieska $\%$ 2Fperziura\%2F-\%2Fexhibit\%2Fpreview\%2F190000010153473\%3 Fs_id\%3DwOHUR1nygVNDbNGT\%26s_ind\%3D86\%26valuable_ type\%3DEKSPONATAS

Vyriausiojo štabo Karo mokslo skyriaus leidinys. Vidaus tarnybos statutas. Kaunas, 1924, p. 28-31 [žr. 2019-01-31]. Prieiga per internetą: http://www.epaveldas.lt/object/recordDescription/LNB/C1B0003709234

Iteikta $2019 \mathrm{~m}$. spalio $22 \mathrm{~d}$. 


\title{
THE CONCEPT OF MILITARY LEADERSHIP IN THE LITHUANIAN ARMED FORCES IN THE PERIOD OF 1930-1940
}

\author{
Lieutenant Commander Remigijus ZABIELA \\ Klaipeda University, Institute of Baltic Region History and Archaeology, \\ Lithuanian Navy
}

The article examines the concept of military leadership in the Lithuanian Armed Forces in the period from 1930 to 1940 based on the analysis of different information sources such as doctrines, education programmes in national archives, opinions, researches in military magazines, etc.

The analysis of the assessment period shows that the topic of military leadership was broadly used but without any systematic approach in most cases. The military doctrines of that time did not adequately address military leadership. The theoretical education of leadership was almost non-existing as the main emphasis was laid upon hands-on training by higher commanders outside the military education institutions. The military journals and magazines represented personal views of the authors normally one-sidedly.

Bringing all three parts together, it is clear that the lack of theoretical background and systematic attitude towards the military leadership topic can only be solved if the pieces of the three parts are brought together into one picture in order to fill the gaps and find connections. Also, it is important to underline that in the examined period there was no definite distinction between a military leader and military leadership as they were understood as one concept.

Summarizing the findings, the military thinkers and writers about the military leadership in the interwar period were rather advanced. The principal terms such as esprit-de-corps, mission command, command and control, decision-making process, higher commander's intent, personal example of the leader and motivational tools have remained equally important today and could be used in modern military leadership 
training.

The findings are also very valuable as they prove that the progress of the Lithuanian Armed Forces from scratch in 1918 to the military capable of massing a hundred thousand soldiers ready to move to any spot in Lithuania within a few days in 1939 was not a coincidence. A great deal of thinking stimulated the progress and the ability of military leadership to control the process was advanced even though leadership training was not the strongest part of it. 